Article

\title{
Pool-Type Fishway Design for a Potamodromous Cyprinid in the Iberian Peninsula: The Iberian Barbel-Synthesis and Future Directions
}

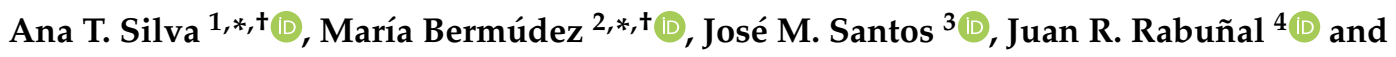 \\ Jerónimo Puertas 5 (iD) \\ 1 Norwegian Institute for Nature Research (NINA), P.O. Box 5685 Torgarden, 7485 Trondheim, Norway \\ 2 Environmental Fluid Dynamics Group, Andalusian Institute for Earth System Research, \\ University of Granada, Av. Del Mediterraneo s/n, 18006 Granada, Spain \\ 3 Forest Research Centre, School of Agriculture, University of Lisbon, 1000 Lisbon, Portugal; \\ jmsantos@isa.ulisboa.pt \\ 4 Centre of Technological Innovation in Construction and Civil Engineering (CITEEC), \\ University of A Coruña, 15001 A Coruña, Spain; juan.rabunal@udc.es \\ 5 Civil Engineering School, University of A Coruña, 15001 A Coruña, Spain; jeronimo.puertas@udc.es \\ * Correspondence: ana.silva@nina.no (A.T.S.); mariabermudez@ugr.es (M.B.) \\ + A.T.S. and M.B. contributed equally to this work and are considered to be co-first authors.
}

Received: 27 February 2020; Accepted: 15 April 2020; Published: 21 April 2020

check for updates

\begin{abstract}
The Iberian barbel (Luciobarbus bocagei) is one of the most common cyprinids in the Iberian Peninsula, whose migratory routes are often hampered by anthropogenic barriers. Fishways might be an effective mitigation measure if they integrate designed operational characteristics that account for the biomechanical requirements of this species. Understanding the flow conditions inside the fishway, and how barbel responds to the hydrodynamics of the flow is imperative to improve free migratory routes with minimum energetic cost associated. Herein, we analyze and synthesize the main findings of research on pool-type fishways for upstream passage of the lberian barbel and derive recommendations of design criteria for pool-type fishways for this species and others of similar biomechanics capacities. Ultimately, we identify research needs to improve upstream passage of this species.
\end{abstract}

Keywords: cyprinids; fishway efficiency; hydraulics; fish behavior; Iberian Peninsula

\section{Introduction}

River fragmentation due to the presence of anthropogenic structures (e.g., dams or weirs) has been identified as one of the main causes of the decline of many fish species [1-7]. There are currently about 7000 large dams in Europe [8], and more than 1400 in the Iberian Peninsula alone (1200 in Spain and 256 in Portugal) [2]. To this we must add smaller barriers whose inventories are largely incomplete: 26,000 and 8000 barriers have been identified in Spanish and Portuguese rivers, respectively, but estimates reach as high as 50,000 [9].

Fishways have been built to restore fish free movement and mitigate the impacts of such barriers on fish populations [10]. Fishways can be classified as natural, technical, and special structures depending on their design [11]. Technical fishways are the most common throughout the world, in particular the so-called pool-type fishways, mainly built at small-hydropower plants [12-15]. Pool-type fishways consist of a sloping-floor channel separated by cross-walls into a series of pools, so that the height to be negotiated by the fish is divided into several small drops [12]. The first devices of this type date back to the nineteenth century $[10,13]$, with many design variations (mainly changes in the pool geometry or in the openings between pools) developed since then (e.g., [16-20]). 
Globally, the translation of fish passage expertise and specific infrastructure have been shown to be largely ineffective and limited in providing real solutions, as different species have contrasting passage requirements $[10,21]$. The design of effective fishways should be region-specific based on the local species [22] and it needs to integrate multidisciplinary knowledge of the fish species behavior, hydrology, and fluid mechanics [23]. The low passage efficiencies found in many existing fishways for potamodromous species and non-salmonid diadromous species [24-26] is a paradigmatic example. This is the result of limited funding available to develop research focused on such species, due to their lower economic value to commercial fisheries and angling when compared to salmonid species. However, best practice in fishway design and the need to comply with water policy tools such as the Water Framework Directive [Directive 2000/60/EC, 2000] is increasingly acknowledging the need to provide passage for a wide range of species and size-classes (i.e., multi-species passage provision), in order to maintain fish community structure and dynamics [27-29]. Species chosen to represent different guilds or key umbrella species can then become the focus in a more holistic community-centered approach.

One such coarse species is the Iberian barbel (Luciobarbus bocagei (Steindachner, 1864)), hereafter barbel, a medium-large sized potamodromous benthic fish endemic to the Iberian Peninsula [30,31]. In addition to the importance of the species itself, the barbel can be a representative species of several medium-large sized benthic potamodromous cyprinids in the Iberian Peninsula and Western Europe (encompassing species from the genera Barbus and Luciobarbus) as it shares similar ecological guilds of physical habitat (benthic), reproduction strategy (lithophilic), and migratory behavior (potamodromous) as well as similar biomechanical features [32,33]. However, scarce information exists on the ecological and biomechanical requirements of this species for upstream passage in a fishway. This, together with a current trial-and-error engineering approach in detriment of a scientific-based decision approach, commonly leads to a low efficiency of passage of fishways to barbel.

In the past years, studies focusing on barbel have grown due to the aforementioned awareness of the need for allowing permanent free movement of the complete fish community in passage facilities [34]. Studies on the swimming performance conducted in respirometers or swim tunnels (e.g., [35]), ecomorphology [32,36,37], and fish biomechanical and physiological response to hydraulics in fishway physical models (e.g., [15,34,38-41]) have been conducted. Although these studies have increased our knowledge of the behavior and hydraulic requirements of the barbel when ascending a fishway, practical guidance into how to develop fishway designs targeting this species is still lacking. This stems partly from the limited knowledge on the response of barbel to various fishways designs [42], but also from the multidisciplinary character of the research needed to address this gap and the lack of systematic reviews of the available literature. To the authors' knowledge, no such extensive review exists for the barbel, despite the studies that have focused on this species in recent years. In this work, we summarize and evaluate the main findings of different research studies that assessed upstream passage of the barbel through pool-type fishways under laboratory and natural conditions. We aim to provide guidelines on design criteria to improve efficiency of passage in pool-type fishways for the barbel and other species of similar biomechanical attributes. Herein, we start by presenting a review of the existing data/knowledge on the swimming performance of the barbel (Section 2), followed by a characterization and comparison of the hydraulics (Section 3) and an overview of conditions tested and the main findings (Section 4) of the fishway studies conducted in the Iberian Peninsula. Finally, we provide guidelines for the design of fishways (Section 5) and future research directions to improve efficiency of passage (Section 6).

\section{Swimming Performance of the Iberian Barbel and Hydrodynamics}

Swimming performance has been postulated as the main characteristic determining survival in many fish species, by setting limits to their capacity to use different habitats for purposes such as feeding and reproduction [43]. Swimming performance results from a physiological and biomechanical strategy to minimize energy expenditure, being highly dependent on the morphological characteristics of a species [44]. Phenotypic diversity of species has been postulated to be the results of both functional trade-offs and 
environment heterogeneity which create different selective pressure on fish [37]. Thus, fish morphology and swimming performance/mode reflect the interaction between fish and the environment and concomitant adaptation of the species to maximize fitness by potential reduction in hydrodynamic resistance and overall energy expenditure during locomotion [45]. Swimming performance of the cyprinid Iberian barbel is a good example of such adaptation. Cyprinidae is the most numerous family of freshwater fish [46] including ca. 2420 species distributed in 220 genera. Largely represented in European rivers, cyprinids comprise $42 \%$ of the freshwater species [47]. They have a long existence in the Iberian Peninsula, with the first fossil of the taxonomic genus Luciobarbus registered 5.5 million of years ago, at the end of the Miocene [48].

With a wide distribution across several river basins from north to central Portugal and Spain, moving between distinct natural hydrological and habitat features, the barbel can exhibit morphological variations among populations. These variations result from different adaptations to the hydrological conditions that the fish are exposed to [37]. Alexandre et al. [32] found different swimming performances and morphologies between two barbel populations from permanent and temporary rivers. The population of barbels that lived in permanent rivers exhibited more fusiform body shape, narrower head and caudal peduncle, and longer and higher pectoral and dorsal fins that allowed them to achieve higher critical swimming to cope with the more unstable and turbulent environment commonly encountered in this type of rivers.

Although, in the last decade, there has been an increased interest in studying the biological-physical interplay of cyprinids species such as the barbel [37-39,41,49], such knowledge is still scarce. A better understanding of the effects of hydromorphological characteristics of the river on the barbel's swimming behavior is crucial to allow the generalization and regional applicability of knowledge ensuring the long-term sustainability of populations of this species and others of similar biomechanical attributes. Misassumptions, as a result of lack of knowledge, can add difficulty to the development of such a process. An example is the assumption, founded in the few data available, that cyprinids are weaker swimmers than salmonids, which has been contrasted by recent studies that showed that specimens from both families are equally good swimmers [50] or that in some cases cyprinids can even be stronger swimmers than salmonids [49]. Sanz-Ronda et al. [49] studied the passage performance of brown trout, barbel, and northern straight-mouth nase through a vertical-slot fishway and found that both cyprinids performed better than the trout when ascending a vertical-slot fishway.

The barbel can travel considerable distances in rivers for feeding, refuge, or spawning purposes. During their journeys, barbel can encounter areas of very high velocities and turbulence due to natural variations on the aquatic systems (e.g., waterfalls) or man-made structures (e.g., small weirs, culverts) that likely hinder their natural volitional movement, increasing the energetic cost of locomotion [51]. Indeed, swimming speed of the Iberian barbel and its fatigue time have been shown to be conditioned by water velocity as well as water temperature, with a dependence on fish length [52,53]. The depletion of available energy at the individual level can reduce fish swimming performance and spawning capacity, with strong implications at the population levels. As such, during their travelling, the barbel preferentially navigates in areas of low velocities $\left(0.2-0.4 \mathrm{~m} \cdot \mathrm{s}^{-1}\right)$ below their critical swimming speed $\left(0.8 \mathrm{~m} \cdot \mathrm{s}^{-1}\right)$ [35].

The behavioral response of fish to hydrodynamics of the flow strongly depends on the temporal perturbation magnitude, species, life stage, and individual size [34,54]. Fish swimming performance and stabilization are strongly impacted by turbulence, in particular by turbulence kinetic energy (TKE) (the kinetic energy associated with fluctuating velocity at a given point) and Reynolds shear stress (RSS) (defined as the continuous transfer of momentum between adjacent viscous water masses of different velocities, intersecting or moving near each other) [34,38,41]. Fish are well adapted to swim under low levels of TKE $\left(<0.05 \mathrm{~m}^{2} \cdot \mathrm{s}^{-2}\right)$ and RSS $\left(<30 \mathrm{~N} \cdot \mathrm{m}^{-2}\right)$ commonly found in small to medium-size streams $[34,39]$. When facing levels of RSS that exceed $60 \mathrm{~N} \cdot \mathrm{m}^{-2}$, fish can become disorientated and lose stability, decreasing their swimming capacity [38]. Moreover, under very high levels of RSS (above $700 \mathrm{~N} \cdot \mathrm{m}^{-2}$ ), fish are likely to become injured or even die [55]. Vortical structures created in turbulent flows also strongly impact swimming performance of the barbel [38]. Depending on their size and orientation, turbulent eddies can cause translational and/or rotational displacement and disorientation 
of fish [56]. The barbel can become disorientated if the eddies are larger than their total length or lose stability and reduce their swimming performance when the size of the eddies equals their size [39]. In addition, eddies smaller than the fish can be used by these to enhance propulsive efficiency when swimming by exploiting the energy associated with such vortical structures $[39,56,57]$. These have been considered to be the hydraulic parameters that impact swimming behavior and sustainability of fish the most, in particular of the Iberian barbel [34,38]. Nonetheless, other hydraulic parameters such as turbulence intensity and volumetric power energy have been shown to affect fish behavior, but to a lower degree. However, consideration of multiple turbulence descriptors may provide a more thorough understanding of the effects of hydrodynamics on fish behavior and movements.

\section{Hydraulics of Pool-Type Fishways}

Fishways are structural mitigation measures whose efficiency strongly depends on how well their design and flow conditions accommodate and suits the biomechanical and ecological requirements of the target species [23,58,59]. Pool-type fishways are hydraulic structures that consist of a sloping-floor channel divided by cross-walls into a series of pools, distributing the total drop over the fishway $(\mathrm{H})$ into several smaller water drops $(\Delta \mathrm{H})$. The drop per pool generally adopted can vary between 0.15 and $0.30 \mathrm{~m}$, and the slope (S) is usually around 10\% [60], although lower slopes are becoming increasingly common $[27,61]$. The slope is a major factor in the construction cost of pool-type fishways, since it determines, together with $\mathrm{H}$, the total length of the fishway. Pool-type fishways may be thus impractical or inappropriate in high-head dams, where alternative fish passage systems such as fish locks or elevators can be implemented [12,62].

Water flows between pools through orifices, notches, or slots in the cross-walls. Each cross-wall can be equipped with a single opening (e.g., a single vertical slot), several openings of the same type (e.g., a double vertical slot), or a combination of opening types (e.g., a side notch and a submerged orifice). Cross-walls are generally vertical and stand at right angles to the pool axis [58]. The arrangement of the openings can vary from aligned to offset between cross-walls, so that they alternate from side to side in two consecutive cross-walls. For examples of cross-wall designs and arrangements in pool-type fishways, the reader is referred to the work of Larinier [11].

According to the geometric characteristics of the cross-walls separating the pools, three different pool-type fishways are considered in this work: orifice fishways (OF) [63,64], notch and orifice fishways (NOF) [63,65], and vertical-slot fishways (VSF) [20,66] (Figure 1). The flow moves between pools through submerged orifices (in the OF case), a combination of surface notches and orifices (NOF), or slots that extend all the way down the cross-wall (VSF). In this classification, the VSF type encompasses the so-called multi-slot fishway, a variant that incorporates two consecutive vertical slots separated by a local widening between each pool, dividing the head drop between the pools into two [67].

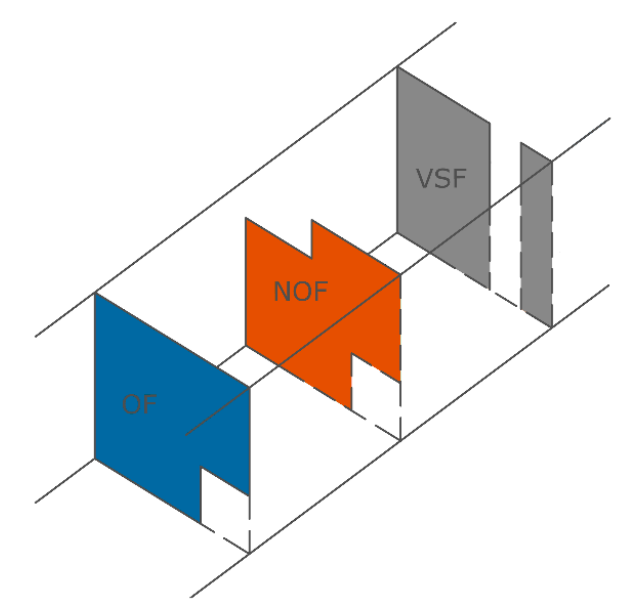

Figure 1. Schematic representation of the three pool-type fishways considered: OF (in dark blue), NOF (in orange), and VSF (in grey). 
Depending on their geometrical design, pool-type fishways exhibit different hydraulic performance varying on: (1) flow regime and flow discharge; (2) water surface profile; and (3) flow pattern, velocity, and turbulence levels in the pools. These aspects are key factors to determine the efficiency of passage of pool-type fishways for different fish species, and will be following described. It should be noted that other aspects such as the location of the entrance could also compromise the biological performance of a fishway. However, this is beyond the scope of this work, and readers are referred to $[11,12]$ for basic guidelines for entrance positions.

\subsection{Flow Regime and Discharge}

Fishways can be located at sites where the flow is limited by operational constraints (e.g., hydropower production) or where large flow reductions can naturally occur [68,69]. It is thus important to determine the discharge needed to operate the fishway, in such a way that hydraulic conditions compatible with fish requirements are ensured as well as hydropower production. For example, a fishway design may become an insurmountable barrier during low flows because the water depth is simply too shallow for fish to swim $[70,71]$.

Different fishway designs require different discharges for equal water depths in the pools. The discharge passing through an orifice or a slot is usually described as follows based on Torricelli's law:

$$
Q=C s \cdot A \cdot \sqrt{2 g \Delta H}
$$

where $C_{S}$ is a discharge coefficient that mainly depends on the shape and form of the opening, $A$ is the flow area in the opening, $g$ is the gravity acceleration, and $\Delta H$ is the drop between pools. Designs with higher $C$ s have a greater flow conveyance efficiency (i.e., for the same flow area in the opening and drop between pools, these designs need a higher discharge).

Two distinguished flow regimes can occur in a notch: streaming and plunging [72]. In streaming mode, the water level in the pool immediately below the cross-wall is above the crest of the notch, and a surface stream appears to flow over the crest of the notches. In the plunging regime, the water level in the downstream pool is lower, which produces a nearly vertical drop over the notch. Depending on the slope, discharge, and configuration of the pools and notches, different sub-regimes can be distinguished between these two major flow regimes [73]. Likewise, the regimen in a slot can be also classified as streaming flow [11], since the water level downstream the slot influences the upstream water level.

To compute the flow through the notch, two discharge coefficients that describe the operation under plunging regime $(C p)$ and streaming regime $(C s)$ are introduced in the Poleni's equation for calculation of flow discharge through a weir [74], as follows:

$$
Q=C p \cdot C s \cdot b \cdot h_{1}^{1.5} \cdot \sqrt{2 g}
$$

where $h_{1}$ is the upstream head at the notch. Cs represents the discharge reduction induced by submergence, which under plunging conditions equals 1 .

Further details on discharge equations, as well as discharge coefficient values of existing fishways, can be found in $[11,58]$.

\subsection{Water Surface Profile}

In the design phase, pool-type fishways are usually planned to operate under uniform flow conditions for a certain total design drop. In these devices, uniform flow is understood as the same mean water depth $(\mathrm{d})$ and water drop $(\Delta \mathrm{H})$ in all pools. Once in operation, the water surface profile in the fishway is, however, frequently non-uniform due to variations in the water levels of the river, which can occur due to hydrological and operational variability. Non-uniformity has a significant impact on the operability of a fishway and should be carefully considered when selecting and designing the fishway type to be implemented [75]. 
If the upstream and downstream water levels in a fishway are subject to similar variations (i.e., they change in synchrony in terms of magnitude and direction), the total drop to overcome will remain the same. The difference in water level from one side to the other of either the orifice or slot $(\Delta \mathrm{H})$ will thus not change significantly, despite the depth variation. The discharge rate will remain almost constant in a $\mathrm{OF}$, given that the area $A$ and the discharge coefficient of the opening $C s$ do not change (see Equation (1)). On the contrary, the flow in VSF and NOF is strongly affected by the variations of the upstream water level (as it changes $A$ in Equation (1) and $h_{1}$ in Equation (2)). In a VSF the flow increases almost linearly with the levels upstream, whereas in a NOF it scales with the 1.5 power. An increase in the upstream water level will thus cause a higher increase in flow discharge in an unsubmerged notch than in a vertical slot, due to the influence of the downstream water levels in this latter type.

Non-synchronous variations in the upstream and downstream water levels of the river are to be expected in the field, and each particular type of fishway will adapt differently to these changes. If the total drop $\mathrm{H}$ differs from the design value, the drop $\Delta \mathrm{H}$ in each pool will change. In the case of an $\mathrm{OF}, \Delta \mathrm{H}$ will be the same in all cross-walls. Changes in the total drop will lead to changes in the water depth, and consequently in the velocity and turbulence in the pools, but with no significant differences between pools. For this reason, $\mathrm{OF}$ are sometimes classified as fishways with autonomous water drop compensation [74]. Conversely, variations from the total design drop will result in gradually varied flow conditions in a VSF and in a streaming flow NOF. Uniform flow will only occur if the average water level slope in the fishway equals the designed bed slope. Otherwise, a conceptual backwater profile (M1) or drawdown profile (M2) will be obtained [76]. This can generate an excessive or insufficient drop $\Delta \mathrm{H}$ in the most downstream cross walls, respectively, and change the velocity and turbulence levels in the pools. This can result in turn in an overall decrease of efficiency of the fishway [77]. In plunging flow NOFs, the effects of variations in the tailwater levels are concentrated at the downstream drop, instead of being distributed through several pools as in VSFs and streaming flow NOFs.

\subsection{Flow Pattern, Velocity Distribution and Turbulence Levels in the Pools}

The flow pattern developed in the pools is key to ensure that fish can pass through them, identifying the upstream direction and minimizing disorientation. Velocity and turbulence levels in the fishway must thus be compatible with the fish swimming capabilities and behavior [34,78]. Fishways should also offer resting areas that allow fish to recover $[79,80]$. This is particularly important for species with weak swimming capabilities and/or in long fishways.

Three different flow patterns are commonly encountered in fishways (Figure 2a-c), which are characterized by a main flow region with a high velocity jet between openings and one or more recirculation regions with lower velocities aside of the main flow. The three flow patterns differ in the number, location, and size of the recirculation eddies and the trajectory of the main flow region. The jet can move straight from one opening to the next, which can lead to the so-called short-circuiting phenomenon [58] (Figure 2a), or it can have a curved form (Figure 2b,c). Two separate recirculation regions, rotating in opposite directions, can also be generated (Figure 2b) instead of a single recirculation area (Figure 2c). Note that these patterns are flexible and can be modified by the placement of artificial structures within the pools, as found by Silva et al. [38] in an OF or by Calluaud et al. [81] in a VSF.

Strongly dependent on the design of the fishway, both the size and the number of the recirculation areas in the pools vary between fishway types $[38,66,82]$. Within the same type, the horizontal flow pattern is affected by the slope, with an increase in the area occupied by the main jet region when the slope increases [66,82]. For a given slope, the flow pattern also depends on the configuration of the pools and the openings (primarily relations among pool length, pool width, and opening width) $[19,82]$. 


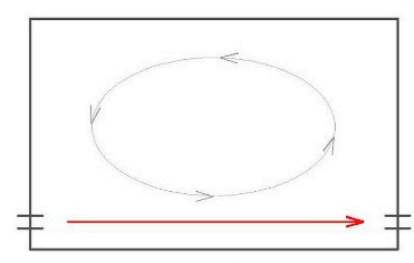

(a)

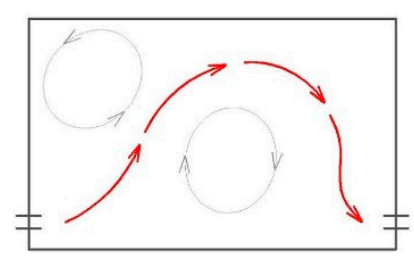

(b)

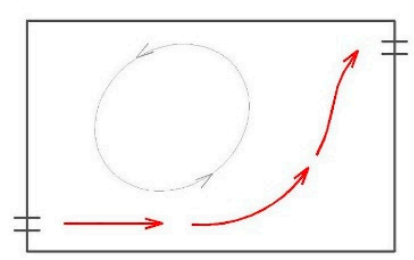

(c)

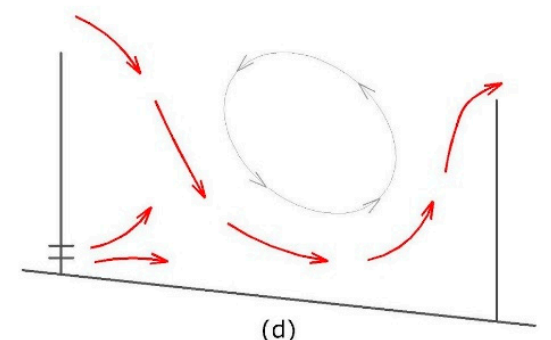

(d)

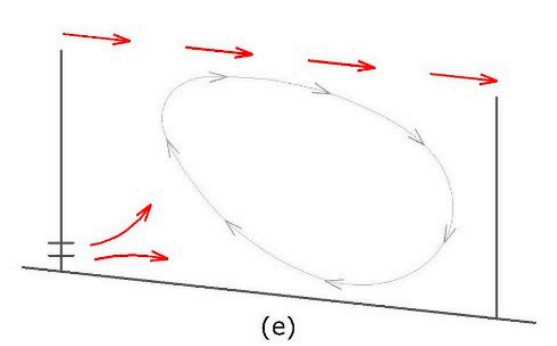

Figure 2. Horizontal circulation patterns in pool-type fishways with aligned openings $(\mathbf{a}, \mathbf{b})$ and offset openings (c). Vertical circulation in a NOF, in plunging flow (d) and streaming flow (e).

For the most commonly used slopes, the velocity field in the pools of a VSF is almost two-dimensional in the horizontal plane, being the velocity practically uniform along the vertical direction. Therefore, the flow patterns described above (Figure 2a-c) are maintained throughout the depth. The hydraulic conditions in VSF are also practically independent of the water levels in the pools, for the same total drop in the fishway $[66,83]$. This stable hydraulic performance under varying discharges is a favorable feature of VSF, compared to OF and NOF, as fish will always experience the same hydraulic conditions. In OF, average water velocities are higher close to the bottom, where the orifices are located, than near the water surface. In the lower planes, the velocity field resembles the flow structures developed in a VSF, as shown in Figure 2a-c. NOF designs exhibit more complex flow patterns, which are clearly three-dimensional. The wide variability in the circulation patterns is dependent upon the pool and cross-wall design, as well as on the discharge supplied, which can change the flow regime between streaming and plunging modes $[73,84]$. A surface stream with high velocities flows over the crest of the notches or slots under streaming regime (Figure 2e), whereas, under plunging regime, a water plunge from the upstream to the downstream pool is formed (Figure 2d). Detailed characterizations of the flow patterns developed in the pools of a NOF can be found in [85]. In the fishway types with a more accentuated three-dimensional flow pattern, high vertical velocity components can exist, which can influence fish behavior, forcing them to shift from one depth to another $[27,86]$.

Simple indicators of the turbulence and agitation levels in the pools such as the volumetric power dissipation are often incorporated in design criteria [87]. However, there is not a unique correspondence between the values of these simple indicators and the turbulence characteristics in the pools, thus further analyses are required to adequately evaluate the performance of any design. The spatial distribution of turbulence within the pools is postulated to play a relevant role in fish passage, and several authors have characterized its variability through turbulence descriptors such as the TKE or the RSS. For detailed characterizations of the velocity and turbulence fields in different pool-type fishway designs, the reader is referred to the works of Silva et al. [38] on OF, Silva et al. [34] on NOF, or Puertas et al. [83] on VSF.

\section{Comparative Passage Performance of Fishway Types for the Iberian Barbel}

Peer-reviewed scientific studies, including ISI Web of Science (WoS) articles and international conference proceedings, were systematically collected using search tools, such as the WoS Core Collection and Google Scholar, and typing the search terms "Iberian barbel" and "fishways". Conference proceedings were only retained for the study, if their content or part of it, was not published as an 
article in a WoS journal. This resulted in a total of 21 contributions (2009-2019) (Table 1), 19 ISI WoS articles and 2 international conference proceedings, totalizing 54 different scenarios tested (Table S1).

Table 1. Summary of the existing studies on pool-type fishways for the Iberian barbel conducted in Iberia between 2009-2019, outlining the type of fishways (NOF, notch and orifice fishway; OF, orifice fishway; VSF, vertical-slot fishway) and the main findings. Detailed information on each of these studies can be found in the Table S1 (Supplementary Materials).

\begin{tabular}{|c|c|c|c|}
\hline Study & Ref. & Type & Main Findings \\
\hline Silva et al., 2009 & [88] & NOF & $\begin{array}{l}\text { Orifices clear choice to negotiate the fishway } \\
\text { Orifices and notches equally used during streaming flow } \\
\text { Orifices used much more than notches during plunging flow }\end{array}$ \\
\hline Quintella et al., 2009 & [89] & OF & EMG telemetry useful to monitor barbel in pool-type fishways \\
\hline Silva et al., 2011 & [34] & OF & $\begin{array}{l}\text { Larger adults with higher passage success than smaller ones } \\
\text { Time to negotiate the fishway lower for larger adults } \\
\text { Horizontal RSS as the most important hydraulic variable }\end{array}$ \\
\hline Silva et al., 2012 & [39] & OF & $\begin{array}{l}\text { Offset orifice configuration better than the straight one } \\
\text { RSS the one that most strongly influenced fish movements }\end{array}$ \\
\hline Silva et al., 2012 & [38] & OF & $\begin{array}{l}\text { Higher passage rates/lower time with offset orifices } \\
\text { Size-related behavioral responses to turbulence } \\
\text { RSS most important turbulence descriptor } \\
\text { Behavior of larger fish strongly affected by eddies }\end{array}$ \\
\hline Alexandre et al., 2013 & [41] & $\mathrm{OF}$ & $\begin{array}{l}\text { Burst swimming was required to move through the orifices } \\
\text { Horizontal RSS as the most important hydraulic variable }\end{array}$ \\
\hline Branco et al., 2013 & [85] & NOF & $\begin{array}{l}\text { Species used the notches more readily during streaming flow } \\
\text { Species more successful during streaming flow } \\
\text { Streaming flow most suitable with different species }\end{array}$ \\
\hline Santos et al., 2013 & [86] & OF & Lower relative depth of flow more beneficial to fish passage \\
\hline Santos et al., 2014 & {$[40]$} & OF & $\begin{array}{l}\text { Fish passage success discharge-related } \\
\text { Fish passage success independent of boulder density } \\
\text { Higher boulder density and discharge lowered time of passage }\end{array}$ \\
\hline Aramburu et al., 2014 & [90] & VSF & $\begin{array}{l}\text { Iberian barbel had higher passage success than Mediterranean } \\
\text { barbel and Iberian nase } \\
\text { Larger fish were more successful in negotiating the fishway } \\
\text { Lower fish passage at higher discharge }\end{array}$ \\
\hline Branco et al., 2015 & [91] & OF & $\begin{array}{l}\text { Boulders: greater fish passage success at higher discharge } \\
\text { Grass: greater fish passage success at lower discharge }\end{array}$ \\
\hline Rodríguez et al., 2015 & [80] & VSF & $\begin{array}{l}\text { Fish avoided high velocity and turbulent areas } \\
\text { Fish rested frequently in the upstream low-velocity areas of } \\
\text { the pools }\end{array}$ \\
\hline Sanz-Ronda et al., 2016 & [49] & VSF & $\begin{array}{l}\text { Barbel and nase ascended easily the VSF } \\
\text { Barbel and nase performed better than trout } \\
\text { Fishway discharge affected fish motivation } \\
\text { Fishway discharge did not influence passage success }\end{array}$ \\
\hline Romão et al., 2017 & [69] & VSF & $\begin{array}{l}\text { No difference in the number of upstream movements between } \\
\text { the slot configurations } \mathrm{C} 1 \text { and } \mathrm{C} 2 \text {. } \\
\mathrm{C} 2 \text { is more cost-effective because it requires less water. }\end{array}$ \\
\hline $\begin{array}{l}\text { Bravo-Cordoba et al., } \\
2018\end{array}$ & [92] & $\mathrm{NOF}$ & $\begin{array}{l}\text { Environmental variables were important for fish entrance. } \\
\text { No preference between path routes } \\
\text { Dual-entrance fishway could be important for conservation }\end{array}$ \\
\hline $\begin{array}{l}\text { Bravo-Cordoba et al., } \\
2018\end{array}$ & [42] & $\begin{array}{l}\text { VSF } \\
+ \\
\text { NOF }\end{array}$ & $\begin{array}{l}\text { Ascent ability in VSF and NOF were similar } \\
\text { Larger fish displayed lower transit time in ascension } \\
\text { Motivation greater in VSF, though not relevant for success }\end{array}$ \\
\hline
\end{tabular}


Table 1. Cont.

\begin{tabular}{lccl}
\hline \multicolumn{1}{c}{ Study } & Ref. & Type & $\begin{array}{l}\text { Main Findings } \\
\text { Fuentes-Pérez et al., 2018 }\end{array}$ \\
& [76] & VSF & $\begin{array}{l}\text { Broader use of the fishway pools with lower head drop } \\
\text { Protection by the walls was key in the use of space } \\
\text { VSF designed with uniform flow can be unsuitable when } \\
\text { non-uniform conditions are present }\end{array}$ \\
\hline Romão et al., 2018 & {$[93]$} & VSF & $\begin{array}{l}\text { No difference in passage performance between VSF and MSF } \\
\text { MSF is preferable as it requires less water (31\%) to operate }\end{array}$ \\
\hline Romão et al., 2018 & {$[94]$} & VSF & $\begin{array}{l}\text { No differences in fish success between spring and autumn } \\
\text { Fish passage evaluation can be extended to early-autumn }\end{array}$ \\
\hline Romão et al., 2019 & {$[95]$} & VSF & $\begin{array}{l}\text { No differences in fish success between spring and autumn } \\
\text { MSF can be considered a cost-effective design for the barbel }\end{array}$ \\
\hline Pedescoll et al., 2019 & [96] & NOF & $\begin{array}{l}\text { Upstream passage efficiency was the greatest for barbel (60\%) } \\
\text { Entry efficiency was low for the barbel (3.8\%) } \\
\text { Fishway has limited efficiency for small fish }\end{array}$ \\
\hline
\end{tabular}

\subsection{Overview of Conditions Tested}

The largest proportion of studies $(\mathrm{n}=17,81 \%)$ were conducted under laboratory experimental conditions, whereas only four (19\%) took place in the field. With regard to the pool-type fishways considered, eight (38.1\%) employed the OF type, eight (38.1\%) the VSF type, four $(19.0 \%)$ the NOF type, and only one $(4.8 \%)$ used two pool-type fishways (NOF + VSF) for comparison. All tested slopes ranged between $6.52 \%$ and $16.3 \%$, with almost all $(\mathrm{n}=17,81 \%)$ within the range of $8.5-10 \%$.

All OF studies were conducted in the lab and included facilities at a constant slope (ca. 8.5\%) with submerged orifices, for which orifice area ranged between 0.03 and $0.06 \mathrm{~m}^{2}$, being 0.04 and $0.05 \mathrm{~m}^{2}$ the most commonly found (64\% of all configurations tested in OF). Pool length and width were 1.9 and 1.0 $\mathrm{m}$, respectively, for all configurations tested. Half of the OF studies had smooth bottom $(n=4,50 \%)$, whereas the other half included additional bottom features placed on the pools, such as deflector bars $(\mathrm{n}=1,12.5 \%$ [38]), boulders ( $\mathrm{n}=3,37.5 \%$ [40,86,91]), and grass rugosities $(\mathrm{n}=1,12.5 \%$ [91]). Concerning the tested flow conditions, flow type was always uniform, ranging from $38.5 \mathrm{~L} \cdot \mathrm{s}^{-1}$ to $77.0 \mathrm{~L} \cdot \mathrm{s}^{-1}$, with variable pool depths $(\mathrm{d}=79-90 \mathrm{~cm})$ and a constant head drop in all studies $(\Delta \mathrm{H}=16 \mathrm{~cm})$.

Half of the NOF studies $(n=2,50 \%)[85,88]$ were conducted in the lab and included the same number of pools (6), the same pool dimensions $(\mathrm{L} \times \mathrm{B}=1.9 \times 1.0 \mathrm{~m})$, the same slope $(8.5 \%)$, and the same orifice area $\left(0.04 \mathrm{~m}^{2}\right.$ ), featuring a uniform flow ranging from $59.3 \mathrm{~L} \cdot \mathrm{s}^{-1}$ to $83.2 \mathrm{~L} \cdot \mathrm{s}^{-1}$ (for plunging flows) and from $78.5 \mathrm{~L} \cdot \mathrm{s}^{-1}$ to $108.3 \mathrm{~L} \cdot \mathrm{s}^{-1}$ (for streaming flows). Width of the surface notches ranged between 20 and $30 \mathrm{~cm}$, with both studies aiming to compare the performance of a plunging vs. a streaming flow regime through the notches. The other two $(50 \%)$ NOF studies were conducted in the field (Douro basin) and included a dual-entrance fishway with 23 pools $(2.6 \mathrm{~m} \times 1.6 \mathrm{~m})$, slopes ranging $8.8 \%-9.8 \%$, and a total flow of $395 \mathrm{~L} \cdot \mathrm{s}^{-1}$ [92] and a 46-pool high slope (16.3\%) fishway, with a flow of $140 \mathrm{~L} \cdot \mathrm{s}^{-1}$ [96]. Orifice area in both fishways ranged $0.02 \mathrm{~m}^{2}-0.06 \mathrm{~m}^{2}$ and their arrangement (as well as those from the lab studies) was set as offset. The width of the notches ranged between $17 \mathrm{~cm}$ and $40 \mathrm{~cm}$, with additional features (boulders) being placed in the pools bottom [49,92]. The head drop between the pools $(\Delta \mathrm{H})$ was higher (range: $25 \mathrm{~cm}-30 \mathrm{~cm})$ than in the lab studies $(\Delta \mathrm{H}=16 \mathrm{~cm})$.

Of all VSF studies, only 1 (12.5\% [49]) was conducted in the field. In the former, the VSF, which encompassed nine pools $(2.4 \mathrm{~m} \times 1.6 \mathrm{~m})$ separated by $20 \mathrm{~cm}$ wide slots, was tested with bottom substrates. The remaining studies $(\mathrm{n}=7,87.5 \%)$ were all conducted under laboratory conditions, with the VSF having been tested for slopes ranging from $7.5 \%$ to $8.5 \%$, with either $6(n=5,71.4 \%[69,76,93-95])$ or $11(\mathrm{n}=2,28.6 \%$ [80,90]) pools $(1.85 \mathrm{~m}-1.9 \mathrm{~m} \times 1.0 \mathrm{~m}-1.5 \mathrm{~m})$, separated by 10 - and $27-\mathrm{cm}$ wide slots, respectively. Of these lab studies, two $(28.6 \%)[93,95]$ employed a variant of VSF, the multi-slot fishway (MSF [97]), featuring two consecutive slots per pool. With regard to the flow conditions, all studies employed a uniform flow, whereas non-uniformity was only tested in one of the cases [76]. 
Flow magnitude $\left(245 \mathrm{~L} \cdot \mathrm{s}^{-1}-402 \mathrm{~L} \cdot \mathrm{s}^{-1}\right)$, head drop $(\Delta \mathrm{H}=20 \mathrm{~cm})$, and mean water depth in the pool $(\mathrm{d}=110 \mathrm{~cm})$ were higher in the field study [49] than in all the lab studies, where such values ranged $50 \mathrm{~L} \cdot \mathrm{s}^{-1}-250 \mathrm{~L} \cdot \mathrm{s}^{-1}, 7.4 \mathrm{~cm}-21.2 \mathrm{~cm}(\Delta \mathrm{H})$, and $30 \mathrm{~cm}-80 \mathrm{~cm}(\mathrm{~d})$, respectively. The lab studies were also characterized by a high variability on the flow conditions: for uniform flows, flow magnitude, head drop, and depth of water ranged $81 \mathrm{~L} \cdot \mathrm{s}^{-1}-250 \mathrm{~L} \cdot \mathrm{s}^{-1}, 14 \mathrm{~cm}-17.8 \mathrm{~cm}(\Delta \mathrm{H})$, and $30 \mathrm{~cm}-80 \mathrm{~cm}(\mathrm{~d})$, respectively. For non-uniform flow, these values were $50 \mathrm{~L} \cdot \mathrm{s}^{-1}, 7.4 \mathrm{~cm}(\Delta \mathrm{H})$, and $71 \mathrm{~cm}(\mathrm{~d})$ for the non-uniform backwater profile $(\Delta \mathrm{H}<\Delta \mathrm{z})$ and $81 \mathrm{~L} \cdot \mathrm{s}^{-1}, 21.2 \mathrm{~cm}(\Delta \mathrm{H})$, and $61 \mathrm{~cm}(\mathrm{~d})$ for the non-uniform drawdown profile $(\Delta \mathrm{H}>\Delta \mathrm{z})$.

Finally, there was one study that employed two different pool-type fishways, a NOF (slope: $8.77 \%$; number of pools $=11$; orifices area $=0.04 \mathrm{~m}^{2}$; and notch width $=30 \mathrm{~cm}$ ) and a VSF (slope: $6.52 \%$; number of pools $=18$; number of slots $/$ pool $=1$; and slot width $=20 \mathrm{~cm}$ ), for comparison of ascent ability and fish motivation [42]. Both fishways featured a uniform flow (range: $250 \mathrm{~L} \cdot \mathrm{s}^{-1}-270 \mathrm{~L} \cdot \mathrm{s}^{-1}$ ) and substrates on the bottom of the pools. $\Delta \mathrm{H}$ was $15 \mathrm{~cm}$ (VSF) and $25 \mathrm{~cm}$ (NOF).

\subsection{Overview of Main Findings}

In this section, experimental evidence of the role played by flow conditions on the successful passage of barbel through different pool-type fishways is presented.

\subsubsection{NOF}

The analysis of main findings from NOF studies conducted in the lab revealed that orifices were the clear choice $(76 \%)$ for the barbel to negotiate these facilities, rather than the notches (24\%) [88], a finding that was also reported for other species, such as the brown trout (Salmo trutta) and the Atlantic salmon (Salmo salar) in a similar design [98]. Silva et al. [88] postulated that, despite the similarity of velocities between the orifices and notches, it is possible that flow from the submerged orifices may have provided a directionally stronger cue to the approaching fish, rather than the notches. In the same study, selection for orifices and notches was also analyzed for plunging and streaming flow regimes. Upon plunging flow conditions, a significant portion (>85\%) of barbel upstream movements were conveyed through the bottom orifices, whereas, during streaming flow conditions, no significant differences were found on the use of the two opening types. In a similar study, barbel also evidenced a higher proportion of successes of passage during streaming flow conditions ( $78 \%$ ) relative to plunging regimes [85]. These results confirm the hypothesis that barbel would be unlikely to use the surface notches during plunging flows due to its weaker leaping abilities (but see Amaral et al. [99]), therefore avoiding the jet core with the highest velocities. Conversely, during streaming flow conditions, the presence of a continuous surface stream flowing over the crest of the notches is likely to have reduced barbel's energy expenditure for swimming by allowing individuals to swim, rather than leap, over the notches, hence the observed similar proportion of fish using both fish pass openings in such conditions. Field studies highlighted the role of key environmental variables, such as flow and water temperature, as triggers of upstream fish migration [92], which typically occurs from spring to early-summer [95,100], which points out the need to conduct fishway studies preferably during this time frame. Another interesting result is that efficiency upon negotiating this type of fishways revealed to be size-related with larger fish displaying a higher efficiency and lower transit time for ascension, relative to smaller ones [42,96].

\subsubsection{OF with Smooth Bottom}

Considering the arrangement of orifices and their influence on barbel movements, it was reported that the offset configuration had a significantly higher rate of fish passage success $(>60 \%)$ than the straight arrangement $(<30 \%)$ and that the time taken to successfully negotiate the fishway was also significantly lower when it featured an offset configuration, in particular for small adults barbel [38,39]. This was explained by the authors as the result of an abrupt variation on water velocity and turbulence levels from the bottom to the surface of the pools with straight orifices arrangement. Such changes detected by the fish might have created high shear stress levels on the fish's body, hindering swimming 
performance and likely reducing the observed success of barbel passage during those conditions. This was confirmed by the presence of higher RSS zones near the bottom of the pools and in the vicinity of the submerged orifices on the straight configuration, particularly at higher flow discharges.

The role of hydraulic parameters - water velocity, TKE, turbulence intensity (TI), and RSS-in barbel upstream movements was also addressed in some of the studies $[34,38,39,41]$. Findings show that the horizontal component of RSS is one of the most influential turbulent parameters influencing barbel movements, in particular of those of the smaller-size individuals (i.e., $<25 \mathrm{~cm}$ total length (TL)), as observed by the significant correlation of the RSS levels with fish transit time [39]. Studies found that larger individuals presented a higher rate of success (ca. 80\%) relative to smaller ones $(<60 \%)$ when orifices were in an offset arrangement [34,39]. Contrarily, barbel performance through the fishway was lower and not size-related under a straight orifice arrangement [38,39]. In such conditions, a higher RSS in the vicinity of the orifice and the presence of more pronounced changes in velocities seemed to have hampered upstream movements causing fish disorientation and loss of equilibrium, compromising their swimming performance.

Similar to RSS, eddies have also been found to strongly affect barbel's swimming performance, with the effect being fish-size dependent. Silva et al. [38] studied the effects of the hydraulics generated by the placement of a deflector bar of 0.5 of the width of the submerged orifice located at 0.2 of the total length of the pool from the inlet orifices in OF with straight orifices arrangement, on barbel's efficiency of passage. Small and large individuals were tested, and also in this case, a size-depend relationship was evident as a high number of smaller fish $(55 \%)$, compared to a low number of larger fish $(15 \%)$, succeeded in passing the fishway [38]. The reduced success of passage of larger individuals and the concomitant higher transit time was explained by the presence of larger eddies of similar size to the fish body length, that were likely to have decreased fish swimming performance from an increase in hydraulic resistance. This was corroborated by the observed behavior of fish that often spread their pectoral fins, which is a typical behavior of fish when trying to restore stability and balance [56].

The use of EMG telemetry revealed as a useful tool to monitor barbel movements in $\mathrm{OF}$, by identifying areas of difficult passage (orifices) where anaerobic burst swimming is required to move through $[41,89]$. This points out to the need of retrofitting the pools with bottom substrates, as a possible mean to aid fish passage, because it may reduce water velocities at the bottom where barbel typically migrates (see below Section 4.2 .3 for details).

\subsubsection{OF with Bottom Substrates}

OF studies also addressed the effect of placing bottom boulders and grass rugosities on barbel fish passage success and fish transit time $[40,86,91]$. In these, it was found that: (i) fish passage success was flow-related, with increased flows $\left(62.7 \mathrm{~L} \cdot \mathrm{s}^{-1}\right)$ inducing a higher proportion of successful negotiations $(50 \%)$, relative to low flows $\left(38.5 \mathrm{~L} \cdot \mathrm{s}^{-1}, 25 \%\right)$; (ii) fish passage success was independent of boulder density at different flows tested $\left(38.5 \mathrm{~L} \cdot \mathrm{s}^{-1}\right.$ and $\left.62.7 \mathrm{~L} \cdot \mathrm{s}^{-1}\right)$; (iii) higher boulder density, coupled with an increased flow, lowered the transit time for successful negotiations; (iv) relative depth of flow (i.e., the ratio between the mean water depth in the pool (d) and the height (h) of the boulders) was a key parameter influencing barbel movements, as lower relative depths (i.e., higher boulders at lower water depths, $1.3<\mathrm{d} / \mathrm{h}<4$ ) were reported to reduce the transit time for successful negotiation, in comparison to higher ones (i.e., $\mathrm{d} / \mathrm{h}>4$ ); and (v) OF bottom covered with artificial grass rugosity yielded a higher proportion of successful negotiations at lower discharges [91]. This significant increase in fish passage success was possibly due to the observed higher velocity gradient at inlet and outlet orifices during high flow conditions, which might have acted as cue for fish upstream navigation, as flow and particularly water velocity changes (acceleration) are known to provide a major cue that fish upstream movement [23]. In contrast to the proportions of successful passage, fish transit time was instead related to boulder-density when the higher discharge was provided, i.e., under these conditions, fish took significantly less time to ascend the fishway with the higher vs. the lower boulder density. It is possible that, under the low boulder density conditions, the higher velocity area leading to 
the upstream orifice caused a significant increase on the transit time. Such findings are in accordance with previous hydraulic studies [101] that demonstrated how denser spacing (higher boulder density) may provide more suitable hydraulic conditions for fish movement between small obstacles due to greater hydraulic heterogeneity.

The analysis of the effects of two different flow regimes on upstream passage of barbel, based on the relative depth $(\mathrm{d} / \mathrm{h})$ of flow (i.e., Regime $1=\mathrm{d} / \mathrm{h}>4$; Regime $2=1.3<\mathrm{d} / \mathrm{h}<4$ ) on the barbel passage success and timing, revealed that despite the similarity in the proportion of success in both flow regimes, fish were able to negotiate the facility in significantly less time in Regime 2 [86]. Although no differences were found between Regimes 1 and 2 on the horizontal velocity patterns at the plane that corresponds to the mid-height of the boulders, there were significant differences between the two regimes when comparing velocities at the plane above the boulders. In the latter, the use of higher boulders in association with lower water depth generated greater water velocity reductions, which resulted in higher spatial hydraulic heterogeneity, creating several small recirculation regions, which are known to aid upstream movements of many fishes in the wild [102]. On the other hand, the presence of large recirculation regions, as observed in Regime 1, may have caused fish disorientation and hence a delay in fish movements (see [54] for a schematic view). Such regions may become traps for the fish, thereby dramatically increasing transit times in the pools [103]. This was particularly evident in the vicinity of the orifices in Regime 1, when some of these fish were seen to spread their pectoral fins in an attempt to stabilize their body position.

\subsubsection{Vertical Slot Fishways (VSF)}

The main findings from VSF studies reveal that the barbel has a superior or similar capacity to ascend a pool-type fishway when comparing to other tested species, such as the Iberian straight-mouth nase (Pseudochondrostoma polylepis), the Mediterranean barbel (Luciobarbus guiraonis), and the trout (Salmo trutta) [49,90]. In the studied conducted with VSF [90], efficiency of passage was size-related, as $74.1 \%(n=60)$ of the individuals greater than $10 \mathrm{~cm}$ TL were able to ascend an experimental VSF with a flow of $100 \mathrm{~L} \cdot \mathrm{s}^{-1}$, whereas only half of them $(49.2 \%, \mathrm{n}=31)$ were only able to do it with a $250 \mathrm{~L} \cdot \mathrm{s}^{-1}$ flow. Similar results were also reported by other authors on the same experimental device [80], who found passage success was the lowest (33.3\%) for the smallest individuals $(10-15 \mathrm{~cm} \mathrm{TL})$, increasing with increasing of fish size- $50 \%$ for individuals of $15-20 \mathrm{~cm}$ TL and further to $80.0 \%$ for individuals of $20-25 \mathrm{~cm}$ TL - and then decreased (41.2\%) for the largest individuals ( $>25 \mathrm{~cm} \mathrm{TL}$ ). In this study, using computer vision techniques [80], fish tracking also showed that individuals avoided high-velocity areas and mainly used the recirculation regions in the upstream part of the pools, in which velocity and turbulence were lower, to move within the pools and for resting before ascending through the high velocity areas of the slots. This preference of barbel for lower velocity and turbulence levels had also been observed for the NOF and OF designs (see previous sections) and is naturally expected since energy expenditures to maintain fish position are typically lower in such areas [104].

The comparison of fishway performance (as measured by the success rate and transit time) between this type of design and the NOF [42] showed that barbel ascent ability was similar between both designs, with more than $90 \%$ of individuals ascending both fishways successfully, with the median transit time to ascend the total water height of $2.25 \mathrm{~m}$, being less than $23 \mathrm{~min}$. The results of this study, therefore, support previous findings that both types of fishways are adequate for barbel passage, although VSF may be less prone to debris clogging, which is particularly important in a remote area with low frequency of maintenance.

Experimental studies focusing on the passage performance of barbel under two slot configurations were also conducted [69]: C1-slot configuration with both a central and lateral baffle and C2-slot configuration with only a lateral baffle, based, respectively, on Designs 1 and 11 proposed by Rajaratman et al. [20], with both configurations being similar in slope, pool length $(\mathrm{L})$ and width $(\mathrm{B})$, slot width $(\mathrm{b})$, head drop between the pools $(\Delta \mathrm{H})$, and the mean water depth in the pool $(\mathrm{d})$. The results show no significant differences in the number of upstream movements, total number of successes, time to first successful negotiation, and time to 
enter the fishway (entrance time). However, despite the similar overall performance, slot configuration C2 required a lower discharge to operate $\left(\mathrm{C} 1=81 \mathrm{~L} \cdot \mathrm{s}^{-1} \mathrm{vs} . \mathrm{C} 1=110 \mathrm{~L} \cdot \mathrm{s}^{-1}\right)$, being therefore a more cost-effective geometry to consider, especially in regions with limited water availability. This slot configuration was then used to compare barbel passage performance and fatigue under two distinct seasons, namely reproductive (spring) and non-reproductive (early-autumn), with results showing no significant differences on passage performance metrics, except for entry efficiency [94]. However, plasma lactate concentration (as a proxy of fatigue) was higher in autumn, suggesting the need to seasonally adapt operation regime of fishways.

The performance of the selected VSF model was then compared with the one of VSF with two slots, the multi-structure vertical-slot fishway (MSF), which considers two consecutive vertical slots separated by a local widening between each pool [93]. The VSF and MSF were tested with the same mean water depth in the pool, slot width, and pool width and length. In both configurations, the hydraulic head drop between pools, $\Delta \mathrm{H}$, was $0.16 \mathrm{~m}$. The MSF presented a twofold number of slots compared with the standard VSF; thus, although in the MSF the $\Delta \mathrm{H}$ was also $0.16 \mathrm{~m}$, this head drop was divided into two becoming approximately $0.08 \mathrm{~m}$ per slot. Comparing both configurations in terms of hydraulic parameters-mean velocity (U), TKE, and RSS-revealed that VSF presented higher overall magnitudes than the MSF design (Figure 2 in Romão et al. [93]). Indeed, flow velocity reached a maximum of $1.9 \mathrm{~m} \cdot \mathrm{s}^{-1}$ in the VSF and $1.4 \mathrm{~m} \cdot \mathrm{s}^{-1}$ in the MSF, both in the vicinity of the slots (i.e., slots 1 and 2 in the VSF and slots 1-4 in the MSF). Correspondingly, the mean velocity magnitude in the pools was $0.4 \mathrm{~m} \cdot \mathrm{s}^{-1}$ (VSF) and $0.3 \mathrm{~m} \cdot \mathrm{s}^{-1}$ (MSF). TKE and RSS also reached higher magnitudes in the VSF occupying larger areas of higher magnitudes in this configuration when compared with the MSF. Different flow patterns were observed between configurations. In the VSF, a large clockwise rotating swirl appeared in the convex part of the jet and another smaller counter-clockwise rotating swirl was formed in the upper left corner of the pool. Streamlines in the MSF presented a dissimilar pattern. In this configuration, a clockwise rotating swirl stood between slots 1 and 2 and a counter clockwise rotating swirl between slots 3 and 4 . Additionally, two other swirls were found in the area between slots 2 and 3: one in the clockwise direction and another rotating in the opposite direction, closer to slot 2. The proximity of these two swirls generated an area with higher TKE and RSS, precisely in the vicinity of slot 2. Fish passage results show a significantly higher number of movements that occurred in the MSF, relative to the VSF [93]. However, despite a higher overall magnitude of hydraulic parameters, mean velocity (U), TKE, and horizontal RSS in the VSF, no differences were found in the entrance time, entry efficiency, and in the number of successes between both types of facilities. Nevertheless, as it requires 31\% less water to operate for the same depth of water within the pools, the MSF was considered as a more discharge-efficient configuration. Similarly, as with the VSF [94], a study was then performed to assess fish passage performance across the same distinct seasons (i.e., spring, the reproductive period, and early-autumn), with results showing once again no seasonal differences in passage performance between the two periods, highlighting the need to further improve attraction and entrance conditions [95]. Nevertheless, the cost-effectiveness of this design type was emphasized when compared to standard VSF, as well as the need to take into account their propensity for clogging due to woody debris.

A recent study [76] considered the effect of non-uniformity of flow conditions tested (the spatial distribution of barbel) in an experimental VSF under three different hydrodynamic scenarios: (i) uniform profile; (ii) non-uniform backwater profile $(\Delta \mathrm{H}<\Delta \mathrm{Z}$ ); and (iii) non-uniform drawdown profile $(\Delta \mathrm{H}$ $>\Delta \mathrm{Z}$ ). The results show that non-uniform scenarios added variability not only between profiles but also between pools within a profile, raising an additional challenge for the fish. It was also found that fish made broader use of the fishway pools in scenarios with lower water drops, which were highly correlated with regions of overall lower turbulence and velocity magnitude. In addition, the protection offered by walls was found to be a determining factor in the use of space as they were associated to calm conditions (i.e., less energy expenditure) and could provide protection and stability. It was therefore concluded that a VSF designed under the assumption of uniform flow conditions may result 
in an adverse hydrodynamic environment for fish under non-uniform conditions, when water drops are higher than the design value.

\section{Guidelines for Design of Fishways}

The following guidelines, derived from the above analyses encompassing a range of different lab and field conditions, are recommended to assist in the design, evaluation, and retrofitting of fishways for the barbel and other cyprinid species of similar biomechanical and ecological requirements:

(1) Conduct fishway studies and evaluations preferably during spring and early-summer when fish are motivated to migrate upstream due to adequate environmental conditions, such as river discharge and water temperature. This should also include the dimensioning of the fishway itself, considering the range of river flows and water levels experienced during this season and the associated topographic works.

(2) Combine surface notches with submerged orifices for barbel passage. Submerged orifices were clearly the preferential route choice of barbel to upstream movements in pool-and-weir fishways ( $>75 \%$ of total movements) so their use should always be encouraged, if possible with surface notches, to provide alternative routes of passage, when the former, which are more easily prone to clogging, become blocked by woody debris. This may be of particular importance in remote locations, where regular checking and maintenance of the fishway is seldom performed.

(3) Provide streaming flow conditions within pool-type fishways whenever surface notches are present. Streaming flow proved to be a more efficient flow regime by facilitating upstream passage. Such conditions should be favored in detriment of plunging ones. Provided that sufficient water is available, this could be achieved by increasing the fishway discharge and allowing submersion of the crest of the notches as a consequence of increasing the water level of the downstream pools.

(4) Encourage the implementation of offset orifice arrangements. Offset orifices were shown to provide a higher passage success and to be more efficient in passing barbel, particularly smaller individuals, with minimal delay. Contrarily, straight orifices arrangements should be avoided as they may cause higher shear stress in the vicinity of the orifices, larger vortices, and more pronounced changes in velocity, which seemed to have hampered upstream movements.

(5) Consider the placement of submerged structures (e.g., artificial or natural boulders) in the pool's bottom. This will allow attenuating the high turbulence levels (particularly, the horizontal RSS) detected in the vicinity of the submerged orifices, which seemed to hamper and delay the movement of small fish. This placement of structural elements should also be favored in the pools itself to reduce the size of potential recirculation regions that might trap fish.

(6) Favor relative depths of flow $(\mathrm{d} / \mathrm{h})$ - as the ratio between the mean water depth in the pool (d) and the height of artificial bottom structures (h) - higher than 4 . This ratio was found to be more beneficial to fish passage since it creates small reverse-flow fields that might aid upstream movements. In addition, it favors the presence of negative vertical (i.e., descendent) velocities that best orientate the fish within the pathways created by such structures.

(7) Use submerged structures embedded on pools bottom at high density, combined with higher fishway discharge. This should be encouraged as it significantly reduced fish transit time; thus, it is particularly important to be considered in case of longer fishways, where the energy expenditure of migrating fish may be higher and hence fish may be more prone to fatigue. If, however, fishway discharge is a constraint, a lower density design should be employed instead, because lower density yielded higher passage success with low discharge. Whichever the case, regular inspections and maintenance of the pools is necessary due to potential clogging by floating and dragged debris.

(8) Provide an adequate fishway discharge, which should be sufficiently attractive for the fish, but not excessive. Fishway discharge is a critical variable as barbel's passage was found to be flow-related, being higher at higher discharges, but not excessively high (flow in the present study encompassed a high variability, i.e., from $38.5 \mathrm{~L} \cdot \mathrm{s}^{-1}$ to $402 \mathrm{~L} \cdot \mathrm{s}^{-1}$ ). The optimal value will 
depend on the size of the fishway considered (larger/wider fishways will require higher flows to adequately operate) and on the range of flow variations in the river. In some cases, it might be important to consider the provision of an extra flow to increase attraction or to provide an additional fish entrance.

(9) Provide water velocities within the pools in the order of $0.40 \mathrm{~m} \cdot \mathrm{s}^{-1}-0.60 \mathrm{~m} \cdot \mathrm{s}^{-1}$. Water velocity within the pools was found to be a key-feature for effective fish passage in pool-type fishways. Water velocities should be sufficiently attractive for fish but should not exceed fish swimming capacity. Excessive velocities and the consequent excessive turbulence will make it difficult for fish to keep oriented while trying to negotiate the fishway. For the barbel, mean water velocities within the pools ranging between $0.40 \mathrm{~m} \cdot \mathrm{s}^{-1}$ and $0.60 \mathrm{~m} \cdot \mathrm{s}^{-1}$ seemed to provide adequate conditions for fishway negotiation.

(10) Provide head drops between pools of $16 \mathrm{~cm}-20 \mathrm{~cm}$. This will provide water velocities in the slots (in case of VSF) of up to $1.7 \mathrm{~m} \cdot \mathrm{s}^{-1}$, therefore below the desirable threshold of $2 \mathrm{~m} \cdot \mathrm{s}^{-1}$ (limited established for cyprinids [105]). Although being dependent on head drop between the pools, such velocities are relatively unaffected by discharge.

(11) Use vertical slots featuring slots with a single lateral baffle. This should be preferred in detriment to those presenting an additional central baffle. Although significant differences between both slot configurations were not found on the number of successful upstream movements, configurations with a single lateral baffle may be a better option, because it requires a lower discharge to operate, making it a more cost-effective design.

(12) Consider the use of multi-slot fishways (MSF) in detriment of standard vertical-slot fishways (VSF). Despite their similar performance in terms of successful negotiations, MSF were shown to be more discharge-efficient than VSF, because they required 31\% less water to operate for the same water depth in the pools. Therefore, velocity and turbulence are expected to present lower magnitudes, which will favor the negotiation by smaller individuals. Nonetheless, managers should bear in mind that due to their lower operational discharge and design characteristics, MSF could lack appropriate attraction flow while being more prone to clogging. To overcome the problem of adequate attraction flow, an additional discharge at the fishway entrance could be provided to increase attraction and make these fishways more competitive with the dominant flow.

(13) Take into consideration the non-uniformity of flow caused by variations in river water levels upon designing and evaluating the performance of fishways. The non-uniform scenarios, namely the "backwater" profile and the "drawdown" profile, were shown to affect fish distribution due to a change in local hydrodynamics of the pool, and should be considered as they are representative for the changes in up- and downstream water levels that naturally occur with changes in river flow over the year. In such cases, fishways may need to be adapted, for example with adaptable sills in the most downstream cross-walls or submerged pre-barrages downstream of the fishway as suggested by Fuentes-Pérez et al. [74].

\section{Missing Pieces and Future Directions}

Despite the studies focusing on barbel upstream fish passage, there is still a lack of knowledge on the rationales that support criteria for the development of passage solutions for this and other fish species of similar ecological and biomechanical skills. This is a complex process that seeks comprehensive ecological, technological, social policy, and economical skills, thus can only be accomplished by the embracement and employment of a full range of disciplines. Fostering a two-way learning process by promoting a science-society-policy interface is then imperative for the development of future successful solutions for fish passage and river management. In this section, we will discuss the missing pieces of fish passages solutions for the barbel and other similar cyprinids and we provide recommendations for the further development of such structures based on an ecological, technological, and social policy integrated approaches. 


\subsection{Science: Ecology and Technology}

A fish passage solution can be defined as successful if it allows fish to approach, enter, and pass the structure with minimal delay and it assures good physical and physiological conditions of fish during post-passage, allowing for a successful spawning and swimming performance, with minimum impact on the community/population associated [106]. However, there are inconsistencies on the definitions and methods used to quantify efficiency of passage [10], leading to the common erroneous assessment of efficiency of passage based on the number of fish that successfully ascend and pass the fishways. This method does not account or provide information on the effort and behavior of fish in the vicinity of the obstruction and during ascent [107], which implies to have a good knowledge on the target species population downstream of the fishways. Until date, few studies have been focused on this topic. This information is crucial to inform and help on the decision-making on where and which type of fish passage solution to implement, thus, monitorization of the fish population downstream of the barrier is needed. The choice of the type of fish passage and concomitant design should also be sustained on profound knowledge on the ecological and biomechanical requirements and skill of the target species. In this work, we highlight that such knowledge is limited for the barbel, thus future research focusing in this thematic should be developed.

Although in the Iberian Peninsula cyprinids species have often been neglected due to their low commercial value [108], these are the dominant group of autochthonous freshwater fish in Mediterranean rivers $[109,110]$ with high ecological relevance. Free instream movement of cyprinids is indispensable for their survival [29], thus future studies using cyprinids as key species must be developed to inform and enhance freshwater river management in the Iberian Peninsula. Moreover, cyprinids are also the most important group of freshwater fish in other parts of the world such as Africa and Eastern Europe, where they are a critical source of food and income, and where they are culturally important (e.g., Eastern Europe [111,112]).

Many cyprinid fish species, such the barbel, can traverse considerable migratory distances within the freshwater systems utilizing different habitats for different functions such as foraging, spawning, and refuge [113]. Dispersal between habitat patches induces seasonal patterns of upstream migration and/or dispersal. This ecological process enables recolonization, gene flow, and population persistence. As such, fish passage for cyprinids needs to allow for free bi-directional passage. Nevertheless, information on downstream migrations of cyprinids, as of the barbel, is scarce. Studies focusing on the ecological requirements and behavior of downstream movement of the barbel and other cyprinid species are vital to provide insights on the ecological requirements of these species to be used to inform future guidelines for technological design of downstream passages for these species in order to ensure their sustainability. Natural-like bypass fishways might emerge as a good solution to facilitate bi-directional passage of barbel as well as of many other cyprinid species. Such fishways are generally a good solution to allow for free passage of several species [11]; they also adapt well to flow variation (common in Mediterranean Rivers) and integrate well with landscape. Future research on the suitability of natural-like bypasses for bi-directional passage of the barbel and similar species should be developed to provide insights for the development and implementation of such facilities in future river management strategies.

Another crucial aspect to be considered is that flow regulation and impoundment affect fish in different life stages, influencing their migration and dispersal period. There is then an urgent global need for better understanding the responses of aquatic life to altered flows likely to be exacerbated by climate change through changes to the hydrographic conditions. Research focusing on future fish passage solutions to altered climate conditions is then needed. Fishways should become more flexible to variation of flow and easier for fish to traverse if environmental conditions constrain fish swimming activity.

Moreover, during their migratory movements, barbel and other cyprinids are often confronted with different anthropogenic obstacles, varying from large dams to small weirs (e.g., high number of barriers in the Iberian Peninsula; see the Introduction). These emerge as external factors of pressure 
that stimulate and impact the physiological and behavioral responses of these species and subsequently their migratory movement. Cumulative impact of pre-barrier experience, effort, and stress of fish upon passing through anthropogenic barriers are factors that need to be quantified. This can be assessed through physiological studies which result in crucial information for the development of design criteria of fish passages. For instance, information on the cumulative efforts and stress of the fish must be considered in the design of a long fishway where the energy expenditure of migrating fish may be higher and hence fish may be more prone to fatigue.

Ultimately, even if a fish passage structure would be perfectly well designed, this does not necessarily mean that such structure will be efficient for up- and downstream passage of the target species, as falsely believed. Fish passages need to undergo regular maintenance to ensure that fish can use it without any constraints or limitations. This aspect, frequently discarded from fish passage plans, emerges as one of the main problems related with the low efficiency of many fish passages in the Iberian Peninsula [114]. Maintenance of a fish passage is crucial and needs to be considered and budget, in future river management plans.

\subsection{Society}

Overall, it is assumed that management of natural resources and concomitant decisions-making are to be founded on science-based knowledge. Management decisions are often based on the most defensible information, and therefore they can become compromised by limited data and results available to the public. This can lead to errors and misconceptions with strong implications on the development of strategies and solutions to improve river connectivity. The lack of information on the ecological requirements of many cyprinid species for free volitional up- and downstream movement in rivers is a good example. Many of the fishways existent in the Iberian Peninsula have been shown to be inefficient to the passage of the barbel and other cyprinids, as they have been constructed using the criteria design existent and available from studies conducted with salmonids [15,34]. It is then undisputed that further scientific knowledge is needed to improve management of riverine systems. This must be integrated with knowledge obtained in Citizen science (defined as the involvement of citizens in scientific research and knowledge production [115]). Due to its ability to gather massive amounts of data at a spatial scale unattainable by professional scientists alone, integration of citizen science can help scientists and managers in their decisions by providing local knowledge and information. For example, fishermen can help to get information about fish population and species existing in freshwater systems, and they can also play and important role, together with local community, in monitoring and maintaining fish passage solutions (e.g., fishways maintenance) by reporting problems related with misfunction (as described in Section 6.1). Foster active networking that promotes dialogue, communication, and exchange of knowledge among scientists, managers and community members is crucial for successful development of strategies and solutions for fish passage and river management. Moreover, citizen science enhances and transforms science communication. A plurality of participatory approaches including in-depth participation of players from industry, policy, and education should be integrated and encouraged in co-creative projects. Opportunities to exchange knowledge, experience, and improve the dialogue among scientists, managers, politicians, stakeholders, and users will allow to collect crucial information for the development of fish passage solutions and therefore crucial to this process. Moreover, media also plays an integrative role in this activity as a successful engagement of media can help to increase the participation of volunteers and find funding opportunities.

In Iberian Peninsula, several operational programs for communication and citizen involvement targeting the restoration of longitudinal connectivity have been undertaken during the past years [2]. These include the Spanish National Strategy for Rivers Restoration, the Portuguese National Strategy for the Removal of Obsolete Hydraulic Infrastructures, Life Águeda (http://www.life-agueda.uevora.pt/), Life Cipriber (https://cipriber.eu/), Life Irekibai (https://www.irekibai.eu/), Life MigratoEbre (https: 
//www.migratoebre.eu), Life Segura Riverlink (www.segurariverlink.eu), and also a program of video-monitoring of the Touvedo fish lift [116].

\subsection{Policy}

Management agencies usually provide directions on key fisheries management and conservation targets that are used by project proponents and contractors to decide on the best options technically and economically feasible to achieve the desired management objectives. The success of this process is often compromised by lack of funds and in some cases by the absence of scientific and engineering capacity to advise or make an informed decision on solutions for improving river connectivity. A shift of jurisdiction that ensures well-developed and defined governances supported by scientific and technological capacity and knowledge is needed. This can be achieved by developing more transparent policies that embrace a participatory mode of evidence creation, as a better integration of scientific and citizen science knowledge. This is the case of the European Water Framework Directive (WFD), enacted in 2000, the main environmental objective of which is achieving "good status" for all rivers by re-establishing the longitudinal connectivity of the European rivers. The WFD also established specific obligations for the inclusion of the public in the planning and management of river basins processes. Facing this new legislation, the water bodies legislation ruling in the Iberian Peninsula was then revised to adopt the news objectives of WFD. In Spain, a new legislation (the 126 bis article of the Regulation of Public Domain Hydraulic, R.D. 1290/2012) was created, which required total or partial removal of obsolete instream obstacles in the public water domain. In Portugal, a ministerial order was created (15/MAMB/2016) requiring the creation of a Working Group of experts to study and identify instream obstacles that are abandoned or considered to be obsolete, in order to propose a plan for their removal.

Supplementary Materials: The following are available online at http://www.mdpi.com/2071-1050/12/8/3387/s1, Table S1. Details of pool-type fishways studies focusing on the Iberian barbel developed in Iberian Peninsula between 2009-2019. Conf.-Configuration; L $\times$ B-Pool length $\times$ width; OF-Orifice fishway, NOF-Notch and orifice fishway, VSF-Vertical slot fishway (Fishway type). Other abbreviations stand as following: Env.-Environment; M-Males, F-females (Fish characteristics); B-Backwater profile, D-Drawdown profile (Flow characteristics); Visual obs.-Visual observations, EMG-Electromyogram, PIT-Passive Integrated Transponder (Fish Monitoring); $\Delta \mathrm{H}$-head drop between the pools; $\mathrm{d}$-mean water depth in the pool. The main findings of each study are also shown.

Author Contributions: Conceptualization, A.T.S. and M.B.; visualization, A.T.S., M.B., J.M.S., and J.R.R.; writing—original draft preparation, A.T.S., M.B., and J.M.S.; writing—review and editing, A.T.S., M.B., J.M.S., J.R.R., and J.P.; and supervision, A.T.S. and M.B.; All authors read and approved the final manuscript.

Funding: A.T.S. was supported by the Norwegian Research Centre for Hydropower Technology-HydroCen (Project No. 257588); M.B. was funded from EU's Horizon 2020 Programme under Marie Sklodowska-Curie Grant Agreement 754446 and UGR Research and Knowledge Transfer Fund-Athenea3i; and J.M.S. was supported by national funds via FCT under the CEEC Institucional 2018 (Ref. 2/ISA/FCT/2018). Forest Research Centre (CEF) is a research unit funded by Fundação para a Ciência e a Tecnologia I.P. (FCT), Portugal (UIDB/00239/2020).

Acknowledgments: M.B., J.R.R., and J.P. would like to acknowledge support from the Spanish Ministry of Economy and Competitiveness (Ministerio de Economía y Competitividad) (Ref. CGL2012-34688) and thank the CITEEC (Centro de Innovación Tecnolóxica en Edificación e Enxeñería Civil) of the University of A Coruña and the Center for Hydrographic Studies of CEDEX for their ongoing collaboration in this research field. Finally, the authors want to thank the three anonymous reviewers for their comments and suggestions that improved this manuscript.

Conflicts of Interest: The authors declare no competing interest.

\section{References}

1. Benitez, J.-P.; Dierckx, A.; Matondo, B.N.; Rollin, X.; Ovidio, M. Movement behaviours of potamodromous fish within a large anthropised river after the reestablishment of the longitudinal connectivity. Fish. Res. 2018, 207, 140-149. [CrossRef] 
2. Ordeix, M.; González, G.; Sanz-Ronda, F.J.; Santos, J.M. Restoring fish migration in the rivers of the Iberian Peninsula. In From Sea to Source 2.0. Protection and Restoration of Fish Migration in Rivers Worldwide; Brink, K., Gough, P., Royte, J., Schollema, P.P., Wanningen, H., Eds.; World Fish Migration Foundation: Groningen, The Netherlands, 2018; pp. 174-179.

3. Santos, R.E.; Pinto-Coelho, R.M.; Fonseca, R.; Simões, N.R.; Zanchi, F.B. The decline of fisheries on the Madeira River, Brazil: The high cost of the hydroelectric dams in the Amazon Basin. Fish. Manag. Ecol. 2018, 25, 380-391. [CrossRef]

4. Mazumder, D.; Williams, R.J.; Wen, L.; Saintilan, N.; Walsh, C.T. Impoundment constraint of fish niche diversity in a temperate Australian river. Hydrobiologia 2016, 771, 195-206. [CrossRef]

5. Olden, J.D.; Kennard, M.J.; Leprieur, F.; Tedesco, P.A.; Winemiller, K.O.; García-Berthou, E. Conservation biogeography of freshwater fishes: Recent progress and future challenges. Divers. Distrib. 2010, 16, 496-513. [CrossRef]

6. Agostinho, A.A.; Pelicice, F.M.; Gomes, L.C. Dams and the fish fauna of the Neotropical region: Impacts and management related to diversity and fisheries. Braz. J. Boil. 2008, 68, 1119-1132. [CrossRef]

7. Dudgeon, D.; Arthington, A.; Gessner, M.O.; Kawabata, Z.-I.; Knowler, D.J.; Lévêque, C.; Naiman, R.J.; Prieur-Richard, A.; Soto, D.; Stiassny, M.L.J.; et al. Freshwater biodiversity: Importance, threats, status and conservation challenges. Boil. Rev. 2005, 81, 163-182. [CrossRef] [PubMed]

8. European Environment Agency. Reservoirs and Dams. 2018. Available online: https://www.eea.europa.eu/ archived/archived-content-water-topic/reservoirs-and-dams (accessed on 14 February 2020).

9. Centro Ibérico de Restauración Fluvial (CIREF). An analysis of river fragmentation in the Spanish river basins. Technical report developed by Ecohidráulica, S.L., Madrid, Spain, 2016. Available online: www.cirefluvial.com (accessed on 19 April 2020).

10. Silva, A.T.; Lucas, M.C.; Castro-Santos, T.; Katopodis, C.; Baumgartner, L.J.; Thiem, J.D.; Aarestrup, K.; Pompeu, P.S.; O’Brien, G.C.; Braun, D.C.; et al. The future of fish passage science, engineering, and practice. Fish Fish. 2017, 19, 340-362. [CrossRef]

11. Larinier, M. Pool fishways, pre-barrages and natural bypass channels. Bull. Français de la Pêche et de la Pisciculture 2002, 54-82. [CrossRef]

12. Clay, C.H.; Eng, P. Design of Fishways and Other Fish Facilities, 2nd ed.; Lewis Publishers, CRC Press: Boca Raton, FL, USA, 2017.

13. Larinier, M.; Marmulla, G. Fish passes: Types, principles and geographical distribution an overview. In Proceedings of the Second International Symposium on the Management of Large Rivers for Fisheries, Phnom Penh, Cambodia, 11-14 February 2003; Volume II, pp. 183-206.

14. Gough, P.; Philipsen, P.; Schollema, P.P.; Wanningn, H. Chapter 5: Solutions for hazards and obstacles. In From Sea to Source: International Guidance for the Restoration of Fish Migration Highways; Regional Water Authority Hunze en Aa's: AD Veendam, The Netherlands, 2012.

15. Santos, J.M.; Silva, A.T.; Katopodis, C.; Pinheiro, P.; Pinheiro, A.N.; Bochechas, J.; Ferreira, M.T. Ecohydraulics of pool-type fishways: Getting past the barriers. Ecol. Eng. 2012, 48, 38-50. [CrossRef]

16. Pena, L.; Puertas, J.; Bermúdez, M.; Cea, L.; Peña, E. Conversion of Vertical Slot Fishways to Deep Slot Fishways to Maintain Operation during Low Flows: Implications for Hydrodynamics. Sustainability 2018, 10, 2406. [CrossRef]

17. Quaresma, A.; Romão, F.; Branco, P.; Ferreira, M.T.; Pinheiro, A.N. Multi slot versus single slot pool-type fishways: A modelling approach to compare hydrodynamics. Ecol. Eng. 2018, 122, 197-206. [CrossRef]

18. Bombač, M.; ČETINA, M.; Novak, G. Study on flow characteristics in vertical slot fishways regarding slot layout optimization. Ecol. Eng. 2017, 107, 126-136. [CrossRef]

19. Bermúdez, M.; Puertas, J.; Cea, L.; Pena, L.; Balairón, L. Influence of pool geometry on the biological efficiency of vertical slot fishways. Ecol. Eng. 2010, 36, 1355-1364. [CrossRef]

20. Rajaratnam, N.; Katopodis, C.; Solanki, S. New designs for vertical slot fishways. Can. J. Civ. Eng. 1992, 19, 402-414. [CrossRef]

21. Baumgartner, L.J.; Marsden, T.; Singhanouvong, D.; Phonekhampheng, O.; Stuart, I.G.; Thorncraft, G. Using an experimentalin situfishway to provide key design criteria for lateral fish passage in tropical rivers: A case study from the mekong river, central Lao Pdr. River Res. Appl. 2011, 28, 1217-1229. [CrossRef]

22. Barrett, J.; Mallen-Cooper, M. The Murray River's 'Sea to Hume Dam' fish passage program: Progress to date and lessons learned. Ecol. Manag. Restor. 2006, 7, 173-183. [CrossRef] 
23. Williams, J.G.; Armstrong, G.; Katopodis, C.; Larinier, M.; Travade, F. Thinking Like a Fish: A Key Ingredient for Development of Effective Fish Passage Facilities at River Obstructions. River Res. Appl. 2011, 28, 407-417. [CrossRef]

24. Mallen-Cooper, M.; Brand, D.A. Non-salmonids in a salmonid fishway: What do 50 years of data tell us about past and future fish passage? Fish. Manag. Ecol. 2007, 14, 319-332. [CrossRef]

25. Noonan, M.J.; Grant, J.W.A.; Jackson, C.D. A quantitative assessment of fish passage efficiency. Fish Fish. 2011, 13, 450-464. [CrossRef]

26. Foulds, W.L.; Lucas, M.C. Extreme inefficiency of two conventional, technical fishways used by European river lamprey (Lampetra fluviatilis). Ecol. Eng. 2013, 58, 423-433. [CrossRef]

27. Marriner, B.A.; Baki, A.B.; Zhu, D.Z.; Cooke, S.J.; Katopodis, C. The hydraulics of a vertical slot fishway: A case study on the multi-species Vianney-Legendre fishway in Quebec, Canada. Ecol. Eng. 2016, 90, 190-202. [CrossRef]

28. Thiem, J.D.; Binder, T.R.; Dumont, P.; Hatin, D.; Hatry, C.; Katopodis, C.; Stamplecoskie, K.M.; Cooke, S.J. Multispecies fish passage behaviour in a vertical slot fishway on the Richelieu River, Quebec, Canada. River Res. Appl. 2012, 29, 582-592. [CrossRef]

29. Lucas, M.C.; Mercer, T.; McGinty, S.; Armstrong, J.D. Development and evaluation of a flat-bed pass. In Advances in Fish Telemetry; Moore, A., Russell, I., Eds.; CEFAS: Suffolk, UK, 2000; pp. 117-127.

30. Ferreira, M.T.; Sousa, L.V.D.C.; Santos, J.M.; Reino, L.; Oliveira, J.; Almeida, P.; Cortes, R.V. Regional and local environmental correlates of native Iberian fish fauna. Ecol. Freshw. Fish 2007, 16, 504-514. [CrossRef]

31. Sociedad Ibérica de Ictiología (SIBIC) Iberian Barbel-Species Info. Available online: http://www.cartapiscicola. es/\#/species/bboc (accessed on 11 September 2018).

32. Kottelat, M.; Freyhof, J. Handbook of European Freshwater Fishes; Publications Kottelat: Cornol, Switzerland, 2007; ISBN 9782839902984.

33. Doadrio, I.; Perea, S.; Garzón-Heydt, P.; González, J.L. Ictiofauna Continental Española: Bases Para su Seguimiento; Ministerio de Medio Ambiente y Medio Rural y Marino, Centro de Publicaciones: Madrid, Spain, 2011; ISBN 9788449111587.

34. Silva, A.T.; Santos, J.M.; Ferreira, M.T.; Pinheiro, A.N.; Katopodis, C. Effects of water velocity and turbulence on the behaviour of Iberian barbel (Luciobarbus bocagei, Steindachner 1864) in an experimental pool-type fishway. River Res. Appl. 2011, 27, 360-373. [CrossRef]

35. Mateus, C.; Quintella, B.; Almeida, P. The critical swimming speed of Iberian barbelBarbus bocageiin relation to size and sex. J. Fish Boil. 2008, 73, 1783-1789. [CrossRef]

36. Roskov, Y.; Ower, G.; Orrell, T.; Nicolson, D.; Bailly, N.; Kirk, P.M.; Bourgoin, T.; DeWalt, R.E.; Decock, W.; Nieukerken, E.; et al. FishBase (version Feb 2018). In Species 2000 E ITIS Catalogue of Life, 2020-02-24; Froese, R., Pauly, D., Eds.; Species 2000; Naturalis: Leiden, The Netherlands; ISSN 2405-8858. Available online: www.catalogueoflife.org/col (accessed on 4 April 2020).

37. Alexandre, C.; Romão, F.; Almeida, P.; Quintella, B.; Ferreira, A.F. Swimming performance and ecomorphology of the Iberian barbel Luciobarbus bocagei (Steindachner, 1864) on permanent and temporary rivers. Ecol. Freshw. Fish 2013, 23, 244-258. [CrossRef]

38. Silva, A.T.; Katopodis, C.; Santos, J.M.; Ferreira, M.T.; Pinheiro, A.N. Cyprinid swimming behaviour in response to turbulent flow. Ecol. Eng. 2012, 44, 314-328. [CrossRef]

39. Silva, A.T.; Santos, J.M.; Ferreira, M.T.; Pinheiro, A.N.; Katopodis, C. Passage efficiency of offset and straight orifices for upstream movements of Iberian barbel in a pool-type fishway. River Res. Appl. 2010, 28, 529-542. [CrossRef]

40. Santos, J.M.; Branco, P.; Katopodis, C.; Ferreira, M.T.; Pinheiro, A.N. Retrofitting pool-and-weir fishways to improve passage performance of benthic fishes: Effect of boulder density and fishway discharge. Ecol. Eng. 2014, 73, 335-344. [CrossRef]

41. Alexandre, C.; Quintella, B.; Silva, A.T.; Mateus, C.; Romão, F.; Branco, P.; Ferreira, M.T.; Almeida, P. Use of electromyogram telemetry to assess the behavior of the Iberian barbel (Luciobarbus bocagei Steindachner, 1864) in a pool-type fishway. Ecol. Eng. 2013, 51, 191-202. [CrossRef]

42. Bravo-Córdoba, F.J.; Sanz-Ronda, F.J.; Ruiz-Legazpi, J.; Valbuena-Castro, J.; Makrakis, S. Vertical slot versus submerged notch with bottom orifice: Looking for the best technical fishway type for Mediterranean barbels. Ecol. Eng. 2018, 122, 120-125. [CrossRef] 
43. Plaut, I. Critical swimming speed: Its ecological relevance. Comp. Biochem. Physiol. Part A Mol. Integr. Physiol. 2001, 131, 41-50. [CrossRef]

44. Lighthill, M.J. Hydromechanics of Aquatic Animal Propulsion. Annu. Rev. Fluid Mech. 1969, 1, 413-446. [CrossRef]

45. Franssen, N.R. Anthropogenic habitat alteration induces rapid morphological divergence in a native stream fish. Evol. Appl. 2011, 4, 791-804. [CrossRef] [PubMed]

46. Nelson, J.S. Fishes of the World, 4th ed.; Wiley: New York, NY, USA, 2006.

47. Wheeler, A.; Lelek, A. The Freshwater Fishes of Europe. Vol. 9. Threatened Fishes of Europe. Copeia 1988, 1988, 1099. [CrossRef]

48. Doadrio, I.; Casado, P. Nota sobre la ictiofauna continental de los yacimientos de la cuenca de Guadix-Baza (Granada). In Geologia y Paleontologia de la Cuenca de Guadix-Baza; Alberdi, M.T., Bonadonna, F.P., Eds.; Museo Nacional de Ciencias Naturales: Madrid, Spain, 1989; pp. 139-150.

49. Sanz-Ronda, F.J.; Bravo-Córdoba, F.; Fuentes-Perez, J.F.; Castro-Santos, T. Ascent ability of brown trout, Salmo trutta, and two Iberian cyprinids-Iberian barbel, Luciobarbus bocagei, and northern straight-mouth nase, Pseudochondrostoma duriense- in a vertical slot fishway. Knowl. Manag. Aquat. Ecosyst. 2016, 417, 10. [CrossRef]

50. Castro-Santos, T. Optimal swim speeds for traversing velocity barriers: An analysis of volitional high-speed swimming behavior of migratory fishes. J. Exp. Boil. 2005, 208, 421-432. [CrossRef] [PubMed]

51. Pavlov, D.S.; Skorobagatov, M.A.; Shtaf, L.G. The critical current velocity of fish and the degree of flow turbulence. Rep. USSR Acad. Sci. 1982, 267, 1019-1021.

52. Ruiz-Legazpi, J.; Sanz-Ronda, F.J.; Fuentes-Pérez, J.F. Influence of environmental and biometric factors on the swimming capacity of the Iberian barbel (Luciobarbus bocagei Steindachner, 1864), an endemic potamodromous cyprinid of the Iberian Peninsula. Limnetica 2018, 37, 251-265. [CrossRef]

53. Sanz-Ronda, F.J.; Ruiz-Legazpi, J.; Córdoba, F.J.B.; Makrakis, S.; Castro-Santos, T.; Sanz-Ronda, F.J. Sprinting performance of two Iberian fish: Luciobarbus bocagei and Pseudochondrostoma duriense in an open channel flume. Ecol. Eng. 2015, 83, 61-70. [CrossRef]

54. Lupandin, A.I. Effect of Flow Turbulence on Swimming Speed of Fish. Boil. Bull. 2005, 32, 461-466. [CrossRef]

55. Cada, G.; Carlson, T.; Ferguson, J.; Richmond, M.; Sale, M. Exploring the Role of Shear Stress and Severe Turbulence in Downstream Fish Passage. In Proceedings of the Waterpower Conference 1999; Brookshier, P.A., Ed.; American Society of Civil Engineers (ASCE): Las Vegas, NV, USA, 1999; p. 10.

56. Tritico, H.M.; Cotel, A.J. The effects of turbulent eddies on the stability and critical swimming speed of creek chub (Semotilus atromaculatus). J. Exp. Boil. 2010, 213, 2284-2293. [CrossRef] [PubMed]

57. Liao, J.C. A review of fish swimming mechanics and behaviour in altered flows. Philos. Trans. R. Soc. B Boil. Sci. 2007, 362, 1973-1993. [CrossRef] [PubMed]

58. FAO. DVWK Fish Passes: Design, Dimensions and Monitoring; Food and Agriculture Organization of the United Nations: Rome, Italy, 2002; ISBN 3895540277.

59. Katopodis, C.; Williams, J.G. Not all fishways are created equal. In Advances in Fish Passage Research. In Proceedings of the 11th International Symposium on Ecohydraulics, Melbourne, Australia, 7-12 February 2016.

60. Katopodis, C. Introduction to Fishway Design; Freshwater Institute, Department of Fisheries and Oceans: Manitoba, ON, Canada, 1992.

61. Bombač, M.; Novak, G.; Mlacnik, J.; ČETINA, M. Extensive field measurements of flow in vertical slot fishway as data for validation of numerical simulations. Ecol. Eng. 2015, 84, 476-484. [CrossRef]

62. Katopodis, C.; Williams, J.G. The development of fish passage research in a historical context. Ecol. Eng. 2012, 48, 8-18. [CrossRef]

63. Rajaratnam, N.; Katopodis, C.; Mainali, A. Pool-orifice and pool-orifice-weir fishways. Can. J. Civ. Eng. 1989, 16, 774-777. [CrossRef]

64. Boiten, W.; Dommerholt, A. Standard design of the Dutch pool and orifice fishway. Int. J. River Basin Manag. 2006, 4, 219-227. [CrossRef]

65. Yagci, O. Hydraulic aspects of pool-weir fishways as ecologically friendly water structure. Ecol. Eng. 2010, 36, 36-46. [CrossRef]

66. Wu, S.; Rajaratnam, N.; Katopodis, C. Structure of Flow in Vertical Slot Fishway. J. Hydraul. Eng. 1999, 125, 351-360. [CrossRef] 
67. Tauber, M.; Mader, D. Hydraulic comparison of standard vertical slot and multi structure slot fish bypass. In Proceedings of the first European IAHR Congress, Edinburgh, UK, 4-6 May 2010.

68. Laine, A.; Jokivirta, T.; Katopodis, C. Atlantic salmon, Salmo salar L., and sea trout, Salmo trutta L., passage in a regulated northern river-Fishway efficiency, fish entrance and environmental factors. Fish. Manag. Ecol. 2002, 9, 65-77. [CrossRef]

69. Romão, F.; Quaresma, A.; Branco, P.; Santos, J.M.; Amaral, S.; Ferreira, M.T.; Katopodis, C.; Pinheiro, A.N. Passage performance of two cyprinids with different ecological traits in a fishway with distinct vertical slot configurations. Ecol. Eng. 2017, 105, 180-188. [CrossRef]

70. USFWS (U.S. Fish and Wildlife Service). Fish Passage Engineering Design Criteria; USFWS, Northeast Region R5: Hadley, MA, USA, 2019.

71. O'Connor, J.; Mallen-Cooper, M.; Stuart, I. Performance, operation and maintenance guidelines for fishways and fish passage works. In Arthur Rylah Institute for Environmental Research Technical Report No. 262 for the Water and Catchments Group, Department of Environment, Land, Water and Planning; Arthur Rylah Institute for Environmental Research, Department of Environment, Land, Water and Planning: Heidelberg, Germany, 2015.

72. Rajaratnam, N.; Katopodis, C.; Mainali, A. Plunging and Streaming Flows in Pool and Weir Fishways. J. Hydraul. Eng. 1988, 114, 939-944. [CrossRef]

73. Ead, S.; Katopodis, C.; Sikora, G.J.; Rajaratnam, N. Flow regimes and structure in pool and weir fishways. J. Environ. Eng. Sci. 2004, 3, 379-390. [CrossRef]

74. Fuentes-Perez, J.F.; Sanz-Ronda, F.J.; De Azagra, A.M.; García-Vega, A. Non-uniform hydraulic behavior of pool-weir fishways: A tool to optimize its design and performance. Ecol. Eng. 2016, 86, 5-12. [CrossRef]

75. Fuentes-Perez, J.F.; García-Vega, A.; Sanz-Ronda, F.J.; Paredes, A.M.D.A. Villemonte's approach: A general method for modeling uniform and non-uniform performance in stepped fishways. Knowl. Manag. Aquat. Ecosyst. 2017, 418, 23. [CrossRef]

76. Fuentes-Perez, J.F.; Branco, P.; Tuhtan, J.A.; Ferreira, M.T.; Kruusmaa, M.; Branco, P. Spatial preferences of Iberian barbel in a vertical slot fishway under variable hydrodynamic scenarios. Ecol. Eng. 2018, 125, 131-142. [CrossRef]

77. Fuentes-Perez, J.F.; Sanz-Ronda, F.J.; Paredes, A.M.D.A.; García-Vega, A. Modeling Water-Depth Distribution in Vertical-Slot Fishways under Uniform and Nonuniform Scenarios. J. Hydraul. Eng. 2014, 140, 06014016. [CrossRef]

78. Puertas, J.; Cea, L.; Bermúdez, M.; Pena, L.; Rodriguez, A.; Rabuñal, J.R.; Balairón, L.; Lara, Á.; Aramburu, E. Computer application for the analysis and design of vertical slot fishways in accordance with the requirements of the target species. Ecol. Eng. 2012, 48, 51-60. [CrossRef]

79. Rodriguez, A.; Bermúdez, M.; Rabuñal, J.R.; Puertas, J.; Dorado, J.; Peña, L.; Balairón, L. Optical Fish Trajectory Measurement in Fishways through Computer Vision and Artificial Neural Networks. J. Comput. Civ. Eng. 2011, 25, 291-301. [CrossRef]

80. Rodriguez, A.; Bermúdez, M.; Rabuñal, J.R.; Puertas, J. Fish tracking in vertical slot fishways using computer vision techniques. J. Hydroinform. 2014, 17, 275-292. [CrossRef]

81. Calluaud, D.; Pineau, G.; Texier, A.; David, L. Modification of vertical slot fishway flow with a supplementary cylinder. J. Hydraul. Res. 2014, 52, 614-629. [CrossRef]

82. Wang, R.; David, L.; Larinier, M. Contribution of experimental fluid mechanics to the design of vertical slot fish passes. Knowl. Manag. Aquat. Ecosyst. 2010, 2. [CrossRef]

83. Puertas, J.; Pena, L.; Teijeiro, T. Experimental Approach to the Hydraulics of Vertical Slot Fishways. J. Hydraul. Eng. 2004, 130, 10-23. [CrossRef]

84. Kim, J. Hydraulic characteristics by weir type in a pool-weir fishway. Ecol. Eng. 2001, 16, 425-433. [CrossRef]

85. Branco, P.; Santos, J.M.; Katopodis, C.; Pinheiro, A.N.; Ferreira, M.T. Pool-Type Fishways: Two Different Morpho-Ecological Cyprinid Species Facing Plunging and Streaming Flows. PLoS ONE 2013, 8, e65089. [CrossRef]

86. Santos, J.M.; Branco, P.; Silva, A.T.; Katopodis, C.; Pinheiro, A.N.; Viseu, T.; Ferreira, M.T. Effect of two flow regimes on the upstream movements of the Iberian barbel (Luciobarbus bocagei) in an experimental pool-type fishway. J. Appl. Ichthyol. 2012, 29, 425-430. [CrossRef]

87. Katopodis, C. Developing a toolkit for fish passage, ecological flow management and fish habitat works. J. Hydraul. Res. 2005, 43, 451-467. [CrossRef] 
88. Silva, A.T.; Santos, J.M.; Franco, A.C.; Ferreira, M.T.; Pinheiro, A.N. Selection of Iberian barbel Barbus bocagei (Steindachner, 1864) for orifices and notches upon different hydraulic configurations in an experimental pool-type fishway. J. Appl. Ichthyol. 2009, 25, 173-177. [CrossRef]

89. Quintella, B.R.; Mateus, C.S.; Silva, A.T.; Ferreira, M.T.; Almeida, P.R. Assessing the Behavioural Response of the Iberian Barbel (Barbus bocagei) in a Pool-And-Weir Type Fishway Prototype Using EMG Telemetry. In Proceedings of the 33rd IAHR Congress, Vancouver, BC, Canada, 9-14 August 2009.

90. Aramburu, E.; Morcillo, F.; Castillo, M.; Lara, A. Research on fish behavior in a fishway in the Hydraulic Laboratory of the Centre for Hydrographic Studies. Conclusions of the experiment period from 2009 to 2012. Ing. Civ. 2014, 173, 33-42.

91. Branco, P.; Santos, J.M.; Katopodis, C.; Viseu, T.; Ferreira, M.T.; Pinheiro, A.N. The influence of bottom rugosity on the performance of upstream fish movements through a pool-type fishway under different discharges. proceedings of the 36th IAHR Congress, The Hague, Netherlands, 28 June-3 July 2015.

92. Bravo-Córdoba, F.J.; Sanz-Ronda, F.J.; Ruiz-Legazpi, J.; Celestino, L.; Makrakis, S. Fishway with two entrance branches: Understanding its performance for potamodromous Mediterranean barbels. Fish. Manag. Ecol. 2017, 25, 12-21. [CrossRef]

93. Romão, F.; Branco, P.; Quaresma, A.; Amaral, S.; Pinheiro, A.N. Effectiveness of a multi-slot vertical slot fishway versus a standard vertical slot fishway for potamodromous cyprinids. Hydrobiologia 2018, 816, 153-163. [CrossRef]

94. Romão, F.; Santos, J.M.; Katopodis, C.; Pinheiro, A.N.; Branco, P. How Does Season Affect Passage Performance and Fatigue of Potamodromous Cyprinids? An Experimental Approach in a Vertical Slot Fishway. Water 2018, 10, 395. [CrossRef]

95. Romão, F.; Quaresma, A.; Santos, J.M.; Branco, P.; Pinheiro, A.N. Cyprinid passage performance in an experimental multislot fishway across distinct seasons. Mar. Freshw. Res. 2019, 70, 881. [CrossRef]

96. Pedescoll, A.; Aguado, R.; Marcos, C.; González, G. Performance of a Pool and Weir Fishway for Iberian Cyprinids Migration: A Case Study. Fishes 2019, 4, 45. [CrossRef]

97. Mader, H.; Brandl, A.; Käfer, S. Design and Function Monitoring of an Enature®Vertical Slot Fish Pass in a Large Potamal River in Carinthia/Austria. Water 2020, 12, 551. [CrossRef]

98. Guiny, E.; Armstrong, J.; Ervine, D.A. Preferences of mature male brown trout and Atlantic salmon parr for orifice and weir fish pass entrances matched for peak velocities and turbulence. Ecol. Freshw. Fish 2003, 12, 190-195. [CrossRef]

99. Amaral, S.; Branco, P.; Katopodis, C.; Ferreira, M.T.; Pinheiro, A.N.; Santos, J.M. To swim or to jump? Passage behaviour of a potamodromous cyprinid over an experimental broad-crested weir. River Res. Appl. 2017, 34, 174-182. [CrossRef]

100. Santos, J.M.; Ferreira, M.T.; Godinho, F.; Bochechas, J.; Ferreira, M.T. Efficacy of a nature-like bypass channel in a Portuguese lowland river. J. Appl. Ichthyol. 2005, 21, 381-388. [CrossRef]

101. Acharya, M.; Kells, J.A.; Katopodis, C. Hydraulics of micro-channels in nature-like fishways. In Proceedings of the 15th Hydrotechnical Conference of the Canadian Society for Civil Engineering, Victoria, BC, Canada, 30 May-2 June 2001.

102. Hinch, S.G.; Rand, P.S. Swim speeds and energy use of upriver-migrating sockeye salmon (Oncorhynchus nerka): Role of local environment and fish characteristics. Can. J. Fish. Aquat. Sci. 1998, 55, 1821-1831. [CrossRef]

103. Tarrade, L.; Texier, A.; David, L.; Larinier, M. Topologies and measurements of turbulent flow in vertical slot fishways. Hydrobiologia 2008, 609, 177-188. [CrossRef]

104. Pavlov, D.S.; Lupandin, A.I.; Skorobogatov, M.A. The effects of flow turbulence on the behavior and distribution of fish. J. Ichthyol. 2000, 40, S232-S261.

105. Larinier, M. Fish passage experience at small-scale hydro-electric power plants in France. Hydrobiology 2008, 609, 97-108. [CrossRef]

106. Castro-Santos, T.; Cotel, A.; Webb, P.W. Fishway evaluations for better bioengineering-an integrative approach. In Challenges for Diadromous Fishes in a Dynamic Global Environment; Haro, A.J., Smith, K.L., Rulifson, R.A., Moffit, C.M., Klauda, R.J., Dadswell, M.J., Cunjak, R.A., Cooper, J.E., Beal, K.L., Avery, T.S., Eds.; American Fisheries Society: Bethesda, MD, USA, 2009; pp. 557-575.

107. Lucas, M.C.; Frear, P.A. Effects of a flow-gauging weir on the migratory behaviour of adult barbel, a riverine cyprinid. J. Fish Boil. 1997, 50, 382-396. [CrossRef] 
108. Roscoe, D.W.; Hinch, S.G. Effectiveness monitoring of fish passage facilities: Historical trends, geographic patterns and future directions. Fish Fish. 2010, 11, 12-33. [CrossRef]

109. Cabral, M.J.; Almeida, J.; Almeida, P.R.; Dellinger, T.; Ferrand de Almeida, N.; Oliveira, M.E.; Palmeirim, J.M.; Queiroz, A.I.; Rogado, L.; Santos-Reis, M. Livro Vermelho dos Vertebrados de Portugal; Instituto de Conservação da Natureza: Lisboa, Portugal, 2005; p. 660.

110. Doadrio, I. Atlas y Libro Rojo de los Peces Continentales de España; Museo Nacional de Ciencias Naturales: Madrid, Spain, 2002; p. 374.

111. Skelton, P.H.; Tweddle, D.; Jackson, P.B.N. Cyprinids of Africa. In Cyprinid Fishes; Springer Science and Business Media LLC: Berlin, Germany, 1991; Volume 3, pp. 211-239.

112. Banarescu, P.; Coad, B.W. Cyprinids of Eurasia. In Cyprinid Fishes: Systematics, Biology, and Exploitation; Springer Science and Business Media LLC: London, UK; New York, NY, USA, 1991; Volume 3, pp. 127-155.

113. Migration of Freshwater Fishes; Wiley: New York, NY, USA, 2001.

114. Santo, M. Dispositivos de Passagem Para Peixes em Portugal; Direcção-Geral dos Recursos Florestais: Lisboa, Portugal, 2005; p. 137.

115. Silvertown, J. A new dawn for citizen science. Trends Ecol. Evol. 2009, 24, 467-471. [CrossRef]

116. Mameri, D.; Rivaes, R.; Oliveira, J.; Pádua, J.; Ferreira, M.T.; Santos, J.M. Passability of Potamodromous Species through a Fish Lift at a Large Hydropower Plant (Touvedo, Portugal). Sustainability 2020, 12, 172. [CrossRef]

(C) 2020 by the authors. Licensee MDPI, Basel, Switzerland. This article is an open access article distributed under the terms and conditions of the Creative Commons Attribution (CC BY) license (http://creativecommons.org/licenses/by/4.0/). 